\title{
Age sensitivity of behavioral tests and brain substrates of normal aging in mice
}

\author{
John A. Kennard and Diana S. Woodruff-Pak* \\ Systems Neuroscience Laboratory, Neuroscience Program and Department of Psychology, Temple University, Philadelphia, PA, USA
}

\section{Edited by:}

Antonio Camins, University of

Barcelona, Spain

\section{Reviewed by:}

Felix Junyent, Centro de

Investigaciones Biomedicas en Red en

Enfermedades Neurodegenerativas,

Spain

Alexander A. Boldyrev, Lomonosov

Moscow State University, Russia

${ }^{*}$ Correspondence:

Diana S. Woodruff-Pak, Systems

Neuroscience Laboratory,

Neuroscience Program and

Department of Psychology, Temple

University, 1701 North 13th Street,

Weiss Hall, Temple University,

Philadelphia, PA 19122, USA.

e-mail: pak@temple.edu
Knowledge of age sensitivity, the capacity of a behavioral test to reliably detect age-related changes, has utility in the design of experiments to elucidate processes of normal aging. We review the application of these tests in studies of normal aging and compare and contrast the age sensitivity of the Barnes maze, eyeblink classical conditioning, fear conditioning, Morris water maze, and rotorod. These tests have all been implemented to assess normal age-related changes in learning and memory in rodents, which generalize in many cases to age-related changes in learning and memory in all mammals, including humans. Behavioral assessments are a valuable means to measure functional outcomes of neuroscientific studies of aging. Highlighted in this review are the attributes and limitations of these measures in mice in the context of age sensitivity and processes of brain aging. Attributes of these tests include reliability and validity as assessments of learning and memory, well-defined neural substrates, and sensitivity to neural and pharmacological manipulations and disruptions. These tests engage the hippocampus and/or the cerebellum, two structures centrally involved in learning and memory that undergo functional and anatomical changes in normal aging. A test that is less well represented in studies of normal aging, the context pre-exposure facilitation effect (CPFE) in fear conditioning, is described as a method to increase sensitivity of contextual fear conditioning to changes in the hippocampus. Recommendations for increasing the age sensitivity of all measures of normal aging in mice are included, as well as a discussion of the potential of the under-studied CPFE to advance understanding of subtle hippocampus-mediated phenomena.

Keywords: Barnes maze, cerebellum, context pre-exposure facilitation effect, eyeblink classical conditioning, fear conditioning, hippocampus, Morris water maze, rotorod

\section{INTRODUCTION}

The concept of age sensitivity in human neuropsychological and psychometric assessment has existed since at least the 1940s (Cattell, 1941, 1943). Early cross-sectional studies (Conrad et al., 1933; Jones and Conrad, 1933) suggested that intellectual abilities peaked in late adolescence and declined thereafter. Later studies that incorporated a longitudinal design challenged this notion, suggesting that some mental abilities were preserved in middle-aged and older adults (Schaie, 1974). A pivotal development in the concept of age-sensitivity was the theory of fluid and crystallized intelligence (Cattell, 1943; Horn and Cattell, 1966, 1967; Horn, 1968, 1975). Using factor analytic techniques, Raymond Cattell and John Horn identified two major components that comprise intelligence. It was the notion of multiple components of intelligence combined with evidence that these factors have different trajectories over the life span that led to the conceptualization of tests that were age sensitive.

A number of behavioral tests of normal aging in animals, including humans, rely to a varying extent on two primary brain regions - the hippocampus and cerebellum. These two structures age at different rates (Woodruff-Pak and Finkbiner, 1995; Green and Woodruff-Pak, 2000; Woodruff-Pak et al., 2009) as a consequence of different mechanisms of normal aging (Woodruff-Pak, 2006; Woodruff-Pak et al., 2010). That the hippocampus and cerebellum age at different rates implies a number of hypotheses about performance differences between young and old animals, which are somewhat parallel to the conclusions of Cattell and Horn about human intelligence. For example, performance on certain tasks should show age-related deficits earlier than others, depending on the neural substrate engaged. Other brain regions are affected by normal aging, though a discussion of these structures is beyond the scope of this review. The behavioral tests included are among the most frequently used in studies of normal aging, thus the focus will be on two of the substrates that support performance in tasks most likely to be implemented in studies of aging.

Behavioral tests such as the Barnes maze, eyeblink classical conditioning (EBCC), fear conditioning, Morris water maze (MWM), and rotorod are consistently used in studies of normal aging. These tests have readily identifiable and well-studied neural substrates and reliably show behavioral evidence of learning. In addition, aged animals are able to complete these tasks, though rates of learning and retention may differ from young animals. The rotorod, Barnes maze, and Morris water maze are primarily conducted with rodents, though human analogs of the MWM utilizing virtual reality exist (Moffat and Resnick, 2002; Berteau-Pavy et al., 2007). Classical fear conditioning can be accomplished in humans as well as rodents, and EBCC has been tested in a number of mammalian species, including humans, non-human primates, cats, rabbits, and rodents. As each test relies on the cerebellum and/or the hippocampus, it is useful to consider different trajectories of aging when evaluating the value of a particular test in terms of refining the body of data on normal aging. 
To the best of our knowledge, a comprehensive analysis of the age sensitivity, or the ability to detect age-related deficits in performance, has not been compiled for behavioral tests in mice, the most commonly used mammalian species for studies of aging. The capability to describe the age sensitivity of the tests is valuable when planning experiments on processes of aging. We review the application of these tests to studies of aging and describe the age sensitivity of each test.

\section{UTILITY OF THE MOUSE SPECIES TO INVESTIGATE NORMAL AGING}

There are a number of benefits provided by using rodents as a mammalian model of aging. Mice have a relatively short life span (C57BL/6 mice: about 26-28 months; Jucker and Ingram, 1997), and the mouse genome has been sequenced. The potential for genetic manipulation in the mouse has led to an increased interest over the previously favored rat model for investigations of the neurobiology of learning, memory, and aging (Ingram and Jucker, 1999; Vogel et al., 2002). In addition, with the extensive knowledge of the mouse genome, the potential for genetically altered mouse models of aging (both normal and pathological) is unrivaled by other mammalian species. The mouse can be used to study the mechanisms of aging from a number of converging methodologies: behavior, genetics, anatomy, physiology, and histology. Given these advantages, mouse models can be useful for studying normal human aging; however, the primary goal of this review is to compare and contrast the behavioral tests employed to study normal aging in mice. Some behavioral tests included in this review were originally developed for rats (e.g., MWM, Barnes maze) but have been modified to accommodate mice. Mice and rats share sufficient genetic ancestry to be discussed together, although performance on some tasks such as the MWM is not identical, primarily because rats swim better than mice (see Whishaw, 1995; Ingram and Jucker, 1999). The main focus will be the mouse literature, but where mouse data are insufficient or absent, results from other species (rat, rabbit) will be included.

\section{CRITERIA TO EVALUATE AGE SENSITIVITY OF BEHAVIORAL TESTS}

Given the wide variety of tests employed to study normal aging in mice, it is useful to develop standard criteria to evaluate age sensitivity. Bartus et al. (1983) created criteria for developing animal models of age-related memory impairment. Their criteria were modified and expanded beyond the original pharmacological scope by Woodruff-Pak (1990). The criteria presented here were determined through an evaluation of the literature but are consistent with both the criteria of Bartus et al. (1983) and Woodruff-Pak (1990). The criteria adopted in this review for evaluating the age sensitivity of behavioral tests of learning and memory include the following:

1. Behavior measured should show reliable deficits in older animals compared to younger animals.

2. The test should avoid confounds from secondary or alternate processes that could account for behavioral differences.

3. The test should avoid food restriction or intense stressors that could weaken older animals and affect performance.
4. Deficits in old animals should mirror those of young animals with experimentally induced lesions to the target neural substrate.

5. Mouse strain variations in the behavior need to be noted, and the behavior should show parallels across multiple species (human and non-human animal).

6. Drugs known to improve behavior in the aged in clinical trials should also improve performance on the test.

7. From a neuroscience perspective, the test should engage neural substrates that support learning and memory (hippocampus and/or cerebellum).

\section{RATIONALE FOR THE FOCUS ON HIPPOCAMPUS AND CEREBELLUM}

The hippocampus is essential for declarative forms of learning and memory. As such, it is the brain structure most frequently studied as a learning and memory substrate. Surprisingly, it is challenging to identify behavioral tasks that are solely dependent on the hippocampus. Most often, other brain structures are also normally engaged or essential. The cerebellum is another structure activated or essential in many learning and memory tasks. Even when controls are introduced to remove the motor aspects of the task, the cerebellum is still essential in learning. Thus, the hippocampus and cerebellum are the central brain substrates in this review.

\section{AGING IN THE HIPPOCAMPUS}

Loss of hippocampal neurons was at one time thought to be a hallmark of normal aging and associated decreases in learning and memory. With the advent of unbiased stereological techniques, evidence for loss of neurons in the hippocampus was invalidated. Results of studies in humans (West, 1993; West et al., 1994) and rodents (Rasmussen et al., 1996) documented stability in the number of hippocampal pyramidal neurons across the life span. Stereological analysis of pyramidal neurons in the hippocampus of CBA mice aged 4-24 months in our lab replicated previous results demonstrating stability of neuron number over most of the adult mouse life span (Woodruff-Pak et al., 2010).

Hippocampal function does decline in normal aging. Agerelated impairment in electrophysiological processes (Barnes, 1999), alterations in synapses (Geinisman et al., 1992), and a decline in neurogenesis (Bondolfi et al., 2004) have been observed. Synaptic inefficiency appears to be a primary cause of age-related performance deficits on tests of learning and memory. Synaptic disruption in the aged hippocampus has been identified in many studies, though this change may be manifested in localized disruptions of hippocampal circuitry (at the subfield level) and not in a global loss of synaptic markers (Nicolle et al., 1999a; Smith et al., 1999). Other potential disruptions of the aged hippocampus may be due to $\mathrm{Ca}^{2+}$ dysregulation of adenlyl cyclase (Mons et al., 2004) or changes in neurogenesis (Bondolfi et al., 2004; van Praag et al., 2005). Age-associated decreases in neurogenesis have been reported in the granule cell layer and hilus of the dentate gyrus between 2 and 18 months in C57BL/6 mice (Bondolfi et al., 2004). Changes included a decrease in proliferation but not survival of new neurons. No decline was reported between 18 and 24 months, though other studies have reported progressive decreases in hippocampal 
neurogenesis through 24 months (Heine et al., 2004). It is important to note that in the majority of studies, the loss of synapses or decrease in hippocampal efficiency is not present in all aged animals. There is a subpopulation of aged animals that shows impairment on spatial memory tasks, and it is these animals that show reductions in hippocampal plasticity and synapse numbers.

\section{AGING IN THE CEREBELLUM}

The cerebellum shows a number of changes in plasticity, cell number, and morphology with age. In an analysis of cerebellar RNA, Popesco et al. (2008) reported a relatively small group of genes affected by normal aging. The age-affected genes appear to be related to lipid biosynthesis, which suggested that changes in conductivity of the cerebellum due to aging are not the result of large-scale cell loss but rather a focused and regulated molecular process. Other research highlights the age-related loss of Purkinje neurons in the cerebellum in humans (Anderson et al., 2003), rats (Larsen et al., 2000), and multiple strains of mouse (Woodruff-Pak, 2006; Woodruff-Pak et al., 2010).

The loss of Purkinje neurons is significantly associated with deficits in learning and memory assessed by 500-ms delay EBCC (Woodruff-Pak, 2006). In addition to a loss of neurons, the morphology of Purkinje cells is altered with age. Older rats have Purkinje cells with a smaller soma volume (Larsen et al., 2000) and defoliation and smaller spiny branchlets (Greenough et al., 1986). A decrease in long-term depression (LTD), indicating reduced synaptic plasticity in the cerebellum has been reported in older ( 8 and 12 month compared to 4 month) CBA mice (Woodruff-Pak et al., 2010). Finally, evidence suggests that the cerebellum shows agerelated deficits earlier than the hippocampus (Woodruff-Pak and Finkbiner, 1995; Woodruff-Pak et al., 2010), which becomes critical when evaluating behavioral tests that rely on both structures.

\section{BEHAVIORAL TESTS AND AGE SENSITIVITY}

Each test included in this review (MWM, Barnes maze, rotorod, EBCC, and fear conditioning) is used in the field of aging research and to some extent is supported by the cerebellum and/or the hippocampus. Tests of attention or sensory function are not considered, as the focus of this review is changes in learning and memory across the life span of the mouse. Appetitive tasks, such as the radial arm maze and instrumental learning tests are not included in this review. Tests that rely on food restriction can differentially affect older animals, leaving them too weak to perform. Tests were included that avoid potential confounds such as food restriction that can impair performance of older animals and bias conclusions of age-related deficits in learning and memory.

\section{MORRIS WATER MAZE}

The Morris water maze (MWM; Figure 1) is a test of spatial ability. It requires the animal to navigate to the location of an escape platform that is hidden under water.

\section{Neural substrates}

This test was originally developed to examine the contribution of the hippocampus to navigation and place learning in the rat (Morris et al., 1982). Rats with total aspiration lesions of the hippocampus were impaired on the MWM, showing longer latencies to find the

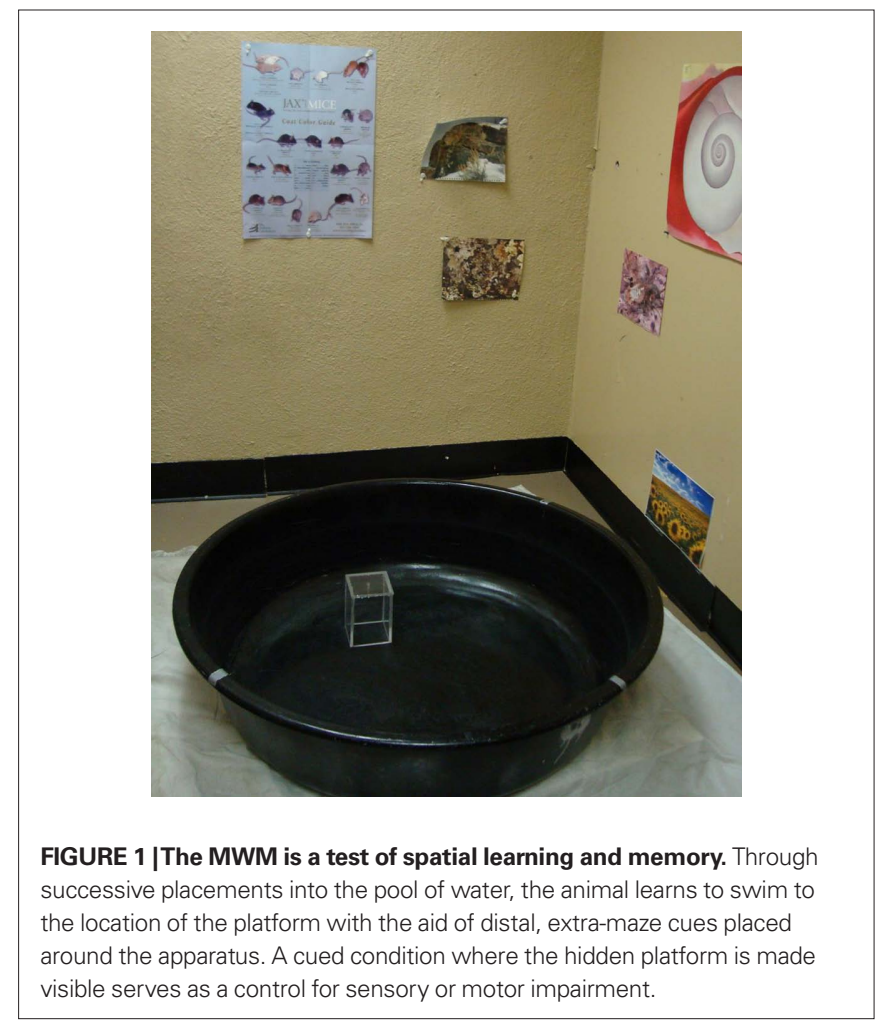

hidden platform and less time swimming in the former location of the platform in a probe retention test (platform removed). Rats with lesions to the hippocampus showed no impairment when the platform was made visible, suggesting that cued learning is not affected. In addition, cognition-enhancing drugs that modulate hippocampal function improve MWM performance in both young rats given pharmacological challenge and old rats that are impaired on the task (Fontana et al., 1995; Yamazaki et al., 1995).

Subsequent research has confirmed the essential role of the hippocampus through lesion studies in mice (Gerlai and Roder, 1996; Logue et al., 1997a) and rats (Gallagher and Nicolle, 1993; van Praag et al., 1998; Gould et al., 2002) and associations between impaired performance and both the functional properties and connectivity of granule cells (Nyffeler et al., 2010). More specifically, the dorsal hippocampus seems to be essential, as lesions to the ventral hippocampus do not impair MWM learning (Bannerman et al., 1999). Though the hippocampus is essential, lesions to the surrounding corticohippocampal circuitry, including the perirhinal, postrhinal, and entorhinal cortices do not impair learning (Burwell et al., 2004). In addition, hippocampus-lesioned rats may still solve the MWM but may use alternate, non-spatial strategies (Pouzet et al., 2002) that involve other brain regions such as the striatum (Miranda et al., 2006). Interventions that increase neurogenesis in the hippocampus, such as voluntary exercise, can also improve spatial-learning ability in the MWM (Kempermann et al., 1997; van Praag et al., 2005).

Another essential brain region for spatial learning in the MWM is the cerebellar cortex. Unilateral removal of a cerebellar hemisphere alters (but does not impair) place learning in DA/ HAN rats (Colombel et al., 2004). Mice with altered currents in 
cerebellar cortical Purkinje neurons due to knockout of a sodium channel-coding gene showed spatial-learning deficits on the MWM (Woodruff-Pak et al., 2006). These mice were not impaired on the cued, visible platform task, which suggests that differences in acquisition and retention of spatial memory were independent of motor deficits. Other studies have implicated the cerebellum in MWM performance through pharmacological lesions of cerebellar cortex (Dahhaoui et al., 1992), irradiation (Le Marec et al., 1997), and lesions to the pontine and inferior olive cerebellar afferents (Gasbarri et al., 2003). Mutant mouse strains with cerebellar cortical dysfunction such as pcd, Lurcher, hot-foot, and staggerer are impaired in acquisition (Goodlett et al., 1992; Lalonde and Strazielle, 2003a). Studies of Lurcher mutant mice suggested that the cerebellum is not necessary for learning a spatial task but plays a crucial role in retention of spatial memory (Hilber et al., 1998).

\section{Age-related deficits}

The MWM is one of the most widely used behavioral tests in studies of normal aging. The task was initially used to study aging in rats. Age deficits in the acquisition of the hidden platform location have been reported in a number of strains including Fisher 344 (Frick et al., 1995), Sprague-Dawley (Gage et al., 1984), Long-Evans (Gallagher and Burwell, 1989), dark agouti (Nyffeler et al., 2010), and Wistar (Miyagawa et al., 1998). Within these strains there have been varying reports of the earliest detectable age deficits in the MWM, though generally by 24-27 months rats show significant impairment. Some studies have reported impairment in acquisition at 18-22 months in Fisher 344 rats (Shukitt-Hale et al., 1998) or as early as 11 months in the same strain (Frick et al., 1995). Strain affects the age of onset of performance deficits. For example, 28-month Long-Evans rats showed no impairment in spatial memory while 28-month Fisher 344 rats were severely impaired (Lindner and Schallert, 1988).

The MWM has been adapted for mice, though a number of issues arise when attempting to compare mouse and rat performance on the test. Mice require more trials for acquisition than rats (Magnusson et al., 2003) and generally perform less well than rats (Whishaw, 1995; Whishaw and Tomie, 1996; Prut et al., 2007). Mice are more sensitive to cold water used in the test (Bellush et al., 1996) and may not be as well adapted to swimming as rats (Prut et al., 2007). In a direct comparison of C57BL/6 mice and LongEvans rats, Whishaw and Tomie (1996) reported impairments in mice relative to rats in terms of place learning when the MWM was used, though performance was equal when place learning was carried out on a dry, radial arm maze. The investigators interpreted these results to indicate that rats are better adapted to swimming in water than mice. Struggling with the motor aspects of swimming may detract from the ability to orient to cues, thus reducing the capacity to perform in the water maze.

Despite the obvious differences between mouse and rat performance in the MWM, a number of studies have included mice to evaluate age differences in spatial memory. Age deficits in mice have been reported in C57BL/6 (Bellush et al., 1996; Magnusson et al., 2003; Harburger et al., 2007), CD1 (Gerlai and Roder, 1996; Francia et al., 2006), NMRI (Gower and Lamberty, 1993), and numerous other inbred and hybrid strains (Markowska et al., 1998; Prut et al., 2007; Harrison et al., 2009a). Age differences have been reported across a number of strains with varying ages of earliest detection. In C57BL/6 mice, age deficits are seen at 24 (Bellush et al., 1996; Magnusson et al., 2003), 18 (van Praag et al., 2005), 15 (Harburger et al., 2007), and as early as 12 months (Wong and Brown, 2007). Gower and Lamberty (1993) reported that from middle age (1112 months) on (to 22 months), deficits in acquisition and retention of spatial memory are apparent and independent of spontaneous locomotor activity, sensorimotor, or emotionality deficits.

There is greater variability across mouse strains on the MWM compared to rats. This perhaps is a reflection of the much larger variety of inbred, outbred, hybrid, and genetically engineered mouse strains used in aging research. Owen et al. (1997) conducted an extensive comparison of MWM performance in 12 mouse strains commonly used for genetic backgrounds and seven hybrid strains. Only the C57BL/6J, C57BL/10J, and 129/SvevTac strains were capable of complex learning across multiple tasks, which included the MWM and fear conditioning. Generally, the albino strains (FVB/ $\mathrm{NJ}, \mathrm{SJL} / \mathrm{J}, \mathrm{A} / \mathrm{J}$, and Bub/Bnj) tested did not demonstrate evidence of learning on the MWM task, though deficits in visual acuity could explain acquisition deficits for some (e.g., FVB/NJ). Other strains such as the $129 / \mathrm{SvJ}$ and DBA/2J-I showed decreasing latencies to escape the pool but no clear evidence of spatial learning when tested in the probe task. Additional research has shown that straindependent differences in visual acuity can confound MWM performance. In a comparison of C57BL/6 and DBA (which develop glaucoma-like symptoms) mice, Wong and Brown (2007) showed no strain difference in MWM performance or visual acuity at 6 months. By 12 months, and continuing through 24 months, DBA mice showed significant impairment on both the MWM and visual acuity tasks. This study highlights contributions of mouse strain to MWM performance and demonstrates that different strains show different developmental trajectories of spatial-learning ability.

\section{Age sensitivity}

The MWM affords a number of benefits in terms of age sensitivity. It does not involve food restriction or the administration of shock to encourage participation of animals (Gage et al., 1984). Memory deficits can be detected independent of sensorimotor impairments (Gage et al., 1989; Gallagher and Burwell, 1989; Miyagawa et al., 1998) through the visible platform, a cued version of the task that is sensitive to deficits in vision and motor function. Several studies have reported age differences in both rats and mice in the acquisition and retention of spatial memory with no group differences seen in the visible platform task (Gerlai and Roder, 1996; Harrison et al., 2009a).

The effects of aging on both performance of the MWM and the neural substrates involved have been corroborated in studies of young lesioned animals. Aged animals (presumably which have endured changes to the hippocampus over time) and young hippocampus-lesioned animals show a similar pattern of deficits in spatial memory (Gallagher and Nicolle, 1993).

Alterations in methodology to improve the age sensitivity of the MWM have been suggested. Many of these changes involve increasing the difficulty of the task, such as incorporating a variable interval probe where the platform is unavailable for a variable amount of time but then is raised (Frick et al., 1995), combined measures of a learning index (de Fiebre et al., 2006) or emphasis 
on dependent measures such as platform crossings in the probe test (Markowska et al., 1998). Crossing the platform location is more difficult than swimming or covering distance in the trained quadrant, the other common measures of the probe test, because it requires a precise spatial memory of the hidden platform location. The increase in difficulty affords a greater ability to detect age deficits. At the very least, multiple measures should be used including latency to escape, distance traveled, and probe components to evaluate accurately age-related deficits (de Fiebre et al., 2006). Using multiple measures becomes especially important in cases where differences in swimming speed arise, as these differences can bias the latency measure (Klapdor and van der Staay, 1996). The combination of a number of measures standard to the MWM with some of the more difficult measures recently applied is consistent with the notion that multiple parameters provide for greater sensitivity in detecting the progression of spatial memory deficits as a function of age (Gallagher et al., 1993; Klapdor and van der Staay, 1996).

Several limitations of the MWM have been noted which may reduce the ability to detect differences in learning and memory independent of confounding factors. Mice take longer to learn the task and may struggle with swimming, thus reducing the ability to compile a spatial map of the pool (Whishaw and Tomie, 1996). Impairment as a function of poor swimming ability may be mistaken for impairment in spatial memory capacity. Differences in swim speed and visual acuity can bias the latency measure of spatial memory acquisition (Klapdor and van der Staay, 1996; Wong and Brown, 2007), though visual acuity is generally controlled for by the visible platform task. Strain and age differences in swim speed have been reported (Klapdor and van der Staay, 1996), though generally age differences in swim speed are not (Francia et al., 2006; Harburger et al., 2007; Harrison et al., 2009a). As long as multiple dependent variables are considered for acquisition (latency, distance traveled) and retention (platform crossings, swim time) of spatial memory, confounds can generally be avoided. Overreliance on one measure at the expense of others can undermine conclusions regarding age differences in spatial memory.

One of the greatest limitations of the MWM that may affect age sensitivity is the stressful nature (for both mice and rats) of the paradigm. Stress suppresses neurogenesis in the hippocampus, and repeated stress can cause atrophy of hippocampal CA3 pyramidal neurons resulting in a decrease in spine density and dendritic arborizations (McEwen and Magarinos, 2001; Rodrigues et al., 2009). The hippocampus is particularly sensitive to increases in stress hormones, since it expresses receptors for circulating adrenal steroids (McEwen et al., 1968). Aguilar-Valles et al. (2005) reported a strong stress response on day 1 in Wistar rats, though gradually the stress response attenuated. Most importantly, corticosterone concentration was negatively correlated with learning ability during the first 3 days of training. Other research confirms the stressful nature of the MWM and the negative impact of glucocorticoids on performance (Barrett et al., 2009; Harrison et al., 2009b). Behavioral tests that assess spatial memory in the absence of swimming-induced stress may be more sensitive to age differences in learning capacity.

In an aged population of rodents, not all of the oldest animals are impaired when tested on the MWM (Gage et al., 1984, 1989; Gallagher and Burwell, 1989; Gower and Lamberty, 1993; Lee et al.,
1994; Miyagawa et al., 1998; Nicolle et al., 1999b). A subgroup of "good" old performers shows spatial memory abilities equal to that of young animals (Gallagher and Burwell, 1989). Old animals that perform as well as young animals also have comparable levels of neurogenesis in the dentate gyrus and elevated levels compared to their chronologically same-aged but poor performing littermates. Heterogeneity in aging research incorporating the MWM is often reported in the rat (Miyagawa et al., 1998; Nicolle et al., 1999b) and to a lesser extent in the mouse (Gower and Lamberty, 1993). It may become a limitation when "good" and "poor" performing old groups are not identified, as there is likely some underlying difference between the two groups that may be differentially affected by experimental manipulations.

The MWM is not a "pure" hippocampus-dependent task. Differential rates of aging in other structures such as cerebellar cortex preclude interpretations about hippocampal aging alone as underlying spatial memory deficits. The cerebellar cortex may be affected by aging before the hippocampus is affected (WoodruffPak et al., 2010); therefore, aging in the cerebellum may initiate age-related deficits in spatial memory performance.

The MWM satisfies four of the criteria to evaluate age sensitivity. Age-related deficits are reported in both mice and rats (Criterion 1 ); though there are some conflicting reports that suggest deficits associated with normal aging may not be detected by the task (see Table 1). These results depend on the type of memory assessed and the species used. Hippocampal and cerebellar damage in young rats and mice mirrors the behavioral deficits of older animals (Criterion 4 ), whereas drugs that have been shown to improve hippocampal function in older animals enhance spatial memory ability (Criterion 6). There are significant strain differences in MWM performance, and the task cannot be termed purely hippocampal, as cerebellar cortex is also essential (Criteria 5 and 7). A human analog of the MWM does exist, but sufficient data regarding human performance during aging have not been collected and the neural substrates have not been mapped for this task in humans. Finally, a major confound in the MWM is the stressful nature of the swim task, which could bias interpretation of age-related differences (Criteria 2 and 3 )

\section{BARNES MAZE}

The circular platform, or Barnes maze (Figure 2), is similar to the MWM in that it is a spatial navigation task. The rodent learns to locate an escape tunnel.

\section{Neural substrates}

The Barnes maze is dependent on the integrity of the hippocampus. Performance on the Barnes maze is impaired when extramaze spatial cues are removed in that animals do not improve across a number of days of testing (Barnes et al., 1980; Pompl et al., 1999). Learning occurs when visual cues are presented to the animal. Mice show a strong preference for using spatial cues to solve the maze (Harrison et al., 2006). In addition, disruptions to the hippocampal formation are associated with deficits in Barnes maze performance, including early postnatal maternal separation (Fabricius et al., 2008) chronic stress (McLay et al., 1998), transgenic Alzheimer's disease mouse models (Pompl et al., 1999), inactivation by drug infusion (Poucet et al., 1991), lesions of the dentate gyrus (McNaughton et al., 1986), or the loss of septo-hippocampal basal 


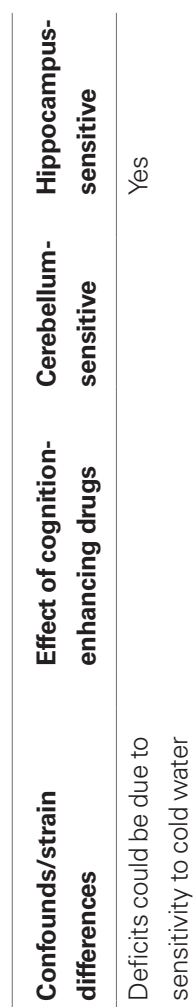

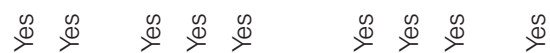

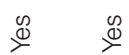

$\stackrel{\infty}{\longleftarrow}$

$\stackrel{2}{2}$

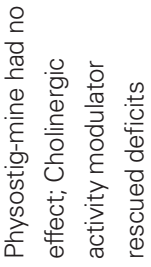

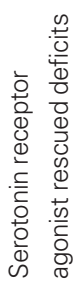

$\stackrel{0}{2}$

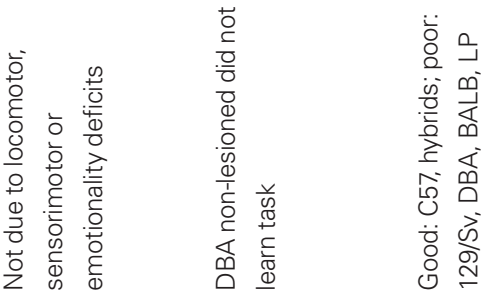

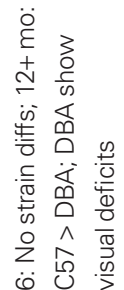
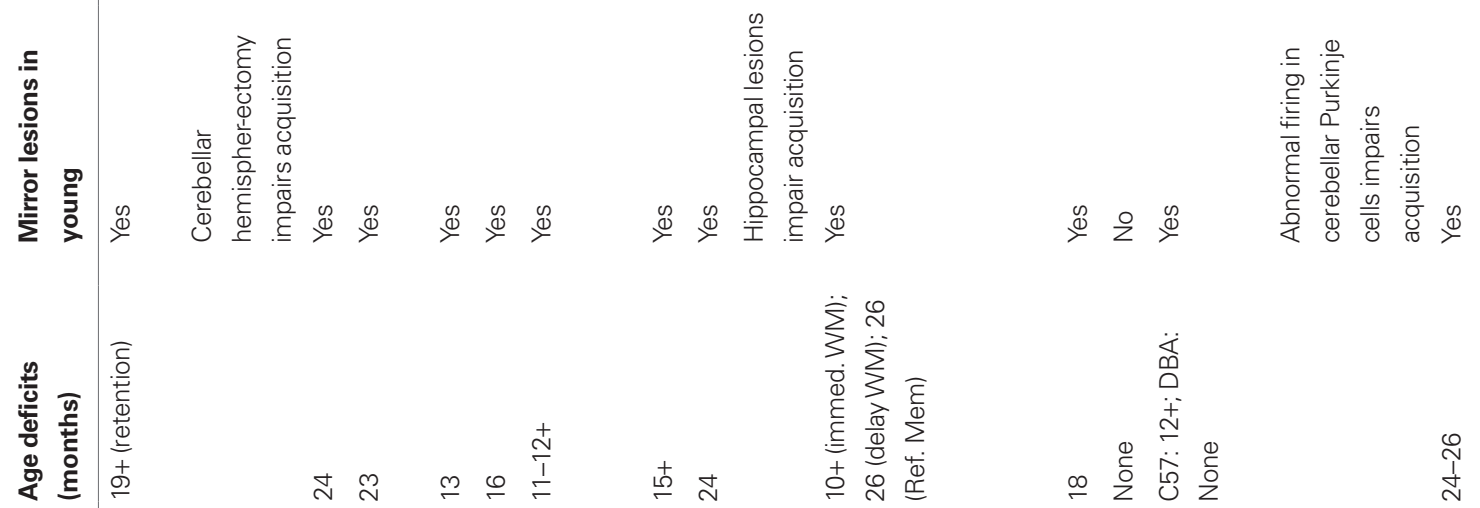

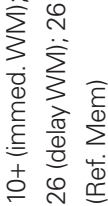

$\stackrel{\infty}{x} 之 \stackrel{\infty}{\infty}$

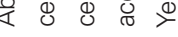
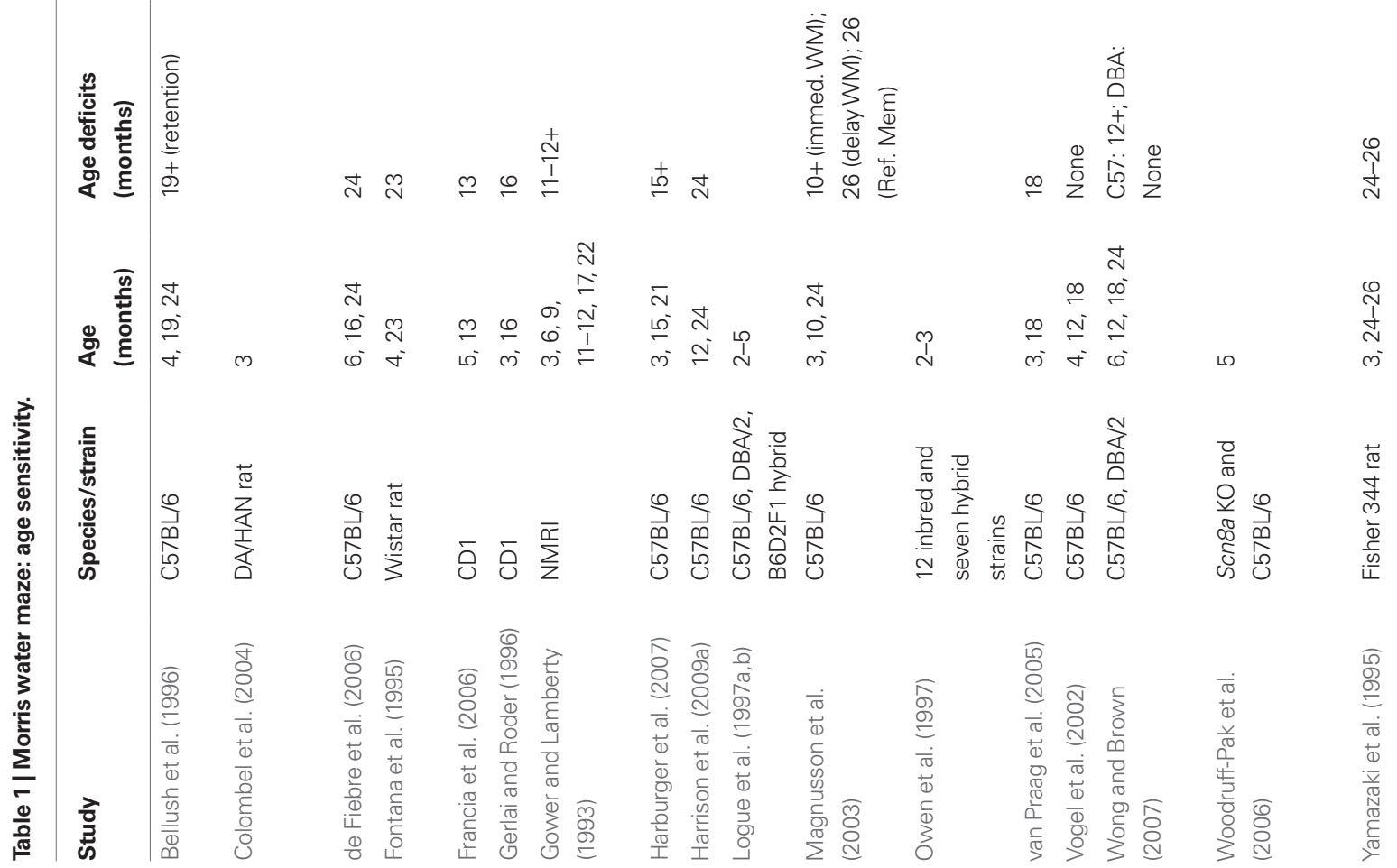

0
0
0
0
0
11
0
0
0
0
0
0
0
0
0
0
0
0
0
0
0
0
0
0
5
0
0
0
0
$ह$
0
0
0
0
0
0
$\omega$ 


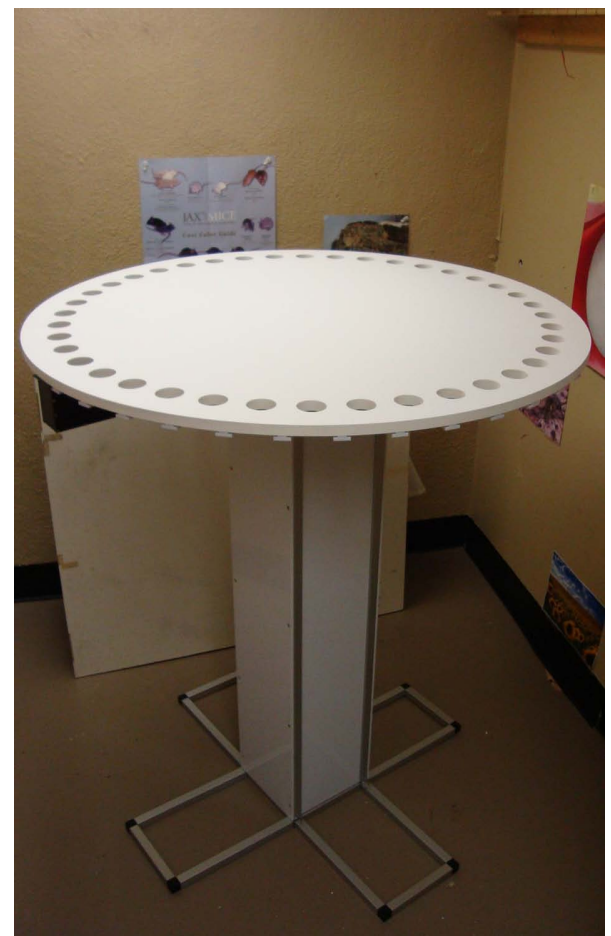

FIGURE 2 |The Barnes maze is a test of spatial memory. The apparatus is a large circular platform with holes spaced evenly around the periphery. The animal is placed in the middle of the platform and is motivated to escape the flat, open surface (necessity of escape is accentuated by bright flood lights shined on the platform). Using spatial cues placed around the platform, the animal learns the location of the single hole, which contains a darkened escape tunnel.

forebrain cholinergic neuron projections (Moreau et al., 2008). In a rodent model of cerebral ischemia, impaired performance was significantly correlated with cell loss in the hippocampus (Milani et al., 1998).Given the role of the cerebellar cortex in supporting MWM performance, it is possible that this structure is involved in the Barnes maze, though the contribution of the cerebellum has not been described. To date, no study has examined Barnes maze performance in cerebellar cortically lesioned or transgenic animals. Further research is necessary to test the hypothesis that the cerebellar cortex is involved in Barnes maze performance.

\section{Age-related deficits}

The Barnes maze was originally constructed for rats, and much of the research using the test utilizes this species. Older rats show impairment on dependent measures of the Barnes maze including latency to reach the goal/escape, the number of errors made (choosing the incorrect hole), speed and distance covered (Barnes, 1979; Barnes et al., 1980; McLay et al., 1999). Barnes (1979) originally reported that senescent Long-Evans rats (28-34 months) were impaired relative to younger rats (10-16 months) on all of the dependent measures. In addition, the older rats were impaired on reversal trials, in which they were required to learn the new location of the escape hole.
Very few studies have employed the Barnes maze to examine age-related deficits in mice. Deficits have been reported in C57BL/6 mice as early as 12 months (Bach et al., 1999). Older animals (12 and 18 month) made more errors than younger (3 and 6 month) and relied more on a serial search strategy rather than a spatial strategy. This is contrary to the original reports of Barnes (1979) in which older rats were able to switch to a spatial strategy. Other studies utilizing the Barnes maze and older mice have not compared multiple ages (Prut et al., 2007). To date, it does not appear that there has been a systematic evaluation of Barnes maze performance across the entire life span of the mouse.

Though few studies of aging mice feature the Barnes maze, a large number of studies have suggested that strain differences in spatial abilities exist (Nguyen et al., 2000; Koopmans et al., 2003). Young adult C57BL/6 mice outperformed CD1 mice on the Barnes maze; however, CD1 mice were superior on the MWM (Patil et al., 2009). Despite the fact that both the MWM and Barnes maze measure spatial memory, results suggest that the two tests do not measure completely overlapping abilities. Koopmans et al. (2003) also reported the behavioral superiority of C57BL/6 mice on the Barnes maze when compared to $129 / \mathrm{Sv}, \mathrm{BALB} / \mathrm{c}$ and Swiss mice. Together, these studies suggest two alternative conclusions: (1) that C57BL/6 mice (and genetic mutants built on this background) are ideal for aging studies investigating spatial memory with the Barnes maze due to their ability to learn the task relative to other strains, or (2) that the superiority of performance of this particular strain of mouse may mask any deficits seen in normal aging.

\section{Age sensitivity}

A limitation of the Barnes maze is that mice do not perform in the same manner as rats (Koopmans et al., 2003). Mice may not always train correctly on the task. They hesitate around the goal hole and explore other holes instead of escaping. These behaviors inflate the measured variables of the test, including latency to escape, distance covered, and number of errors made. Positive reinforcement (i.e., sugar in the escape chamber) appears to improve performance of mice on this task (Grootendorst et al., 2001), though this strategy undermines the original elegance of the Barnes maze that required no stress or food reinforcers to elicit the behavior. To avoid the need for reinforcers, Koopmans et al. (2003) used a modified version of the Barnes maze. Instead of requiring mice to climb through a hole and into an escape tunnel under the board, the investigators placed holes in the wall surrounding the platform area. Mice were much more likely to walk through the holes in the wall surrounding the platform than to climb down into an escape hole.

Instead of altering the construction of the maze, researchers have suggested other methods to control the bias created in the standard variables by the exploratory behavior of mice. Harrison et al. (2006) calculated latency, path length, and number of errors, but only until the first encounter of the escape hole. Other researchers have adopted this solution (Patil et al., 2009) as it is a better indication of whether the mouse learned the location of the escape hole and can show performance differences that are not captured by total path length, total latency, and total errors.

The most important characteristic that distinguishes the Barnes maze from the MWM is stress (Sternberg et al., 1992; Barrett et al., 2009; Harrison et al., 2009b). Both the Barnes maze and MWM 
increase levels of stress hormones compared to non-tested controls, but plasma corticosterone levels were significantly higher in the MWM compared to the Barnes maze (Harrison et al., 2009b). On the MWM (but not the Barnes maze), behavioral performance was inversely correlated with corticosterone levels. The original rationale of Barnes (1979) in creating the maze was that it involved no stressors, shocks, or food restriction, all of which could weaken or impair older rats and confound measures of age differences in learning and memory. Therefore, the Barnes maze seems to be sensitive to similar disruptions in hippocampal function as the MWM but is less physically demanding and less prone to confounding variables such as stress. These qualities would suggest that the Barnes maze should be more sensitive to aging in the hippocampus than the MWM.

Aged rats are impaired in aspects of spatial memory assessed by the Barnes maze and similar results have been reported in mouse populations (Criterion 1), though the mouse literature is less extensive (see Table 2). The Barnes maze may elevate stress, but increased stress is not associated with performance deficits (Criteria 2 and 3). This is not true for the MWM, as stress is both greater and associated with impaired performance. Lesions to the hippocampus of young rats lead to performance deficits similar to those of aged rats (Criterion 4). The Barnes maze, much like the MWM, seems to be affected by strain, as performance varies across a number of mouse and rat strains (Criterion 5). The effect of cognition-enhancing drugs on Barnes maze performance has not yet been sufficiently explored as preliminary studies (Ambrée et al., 2009) have generally focused on pathological rather than normal aging (Criterion 6). However, dopamine $\mathrm{D}_{1} / \mathrm{D}_{5}$ receptor agonists rescue both performance and electrophysiological deficits in aged (12-18 month) C57BL/6 mice compared to young (3-6 month) mice (Bach et al., 1999). Finally, the contribution of the cerebellum to spatial memory as measured by the Barnes maze has not

\begin{tabular}{|c|c|c|c|c|c|c|c|c|}
\hline Study & Species/strain & $\begin{array}{l}\text { Age } \\
\text { (months) }\end{array}$ & $\begin{array}{l}\text { Age deficits } \\
\text { (months) }\end{array}$ & $\begin{array}{l}\text { Mirror } \\
\text { lesions } \\
\text { in } \\
\text { young }\end{array}$ & $\begin{array}{l}\text { Confounds/strain } \\
\text { differences }\end{array}$ & $\begin{array}{l}\text { Effect of } \\
\text { cognition- } \\
\text { enhancing } \\
\text { drugs }\end{array}$ & $\begin{array}{l}\text { Cerebellum- } \\
\text { sensitive }\end{array}$ & $\begin{array}{l}\text { Hippocampus- } \\
\text { sensitive }\end{array}$ \\
\hline $\begin{array}{l}\text { Arendash } \\
\text { and King } \\
(2002)\end{array}$ & $\begin{array}{l}\text { Tg2576, } \\
\text { C57BL/6 }\end{array}$ & $3,14,19$ & C57: $14<3,19$ & Yes & $\begin{array}{l}\text { May involve } \\
\text { sensorimotor and/or } \\
\text { anxiety components }\end{array}$ & & & No \\
\hline $\begin{array}{l}\text { Bach et al. } \\
\text { (1999) }\end{array}$ & C57BL/6 & $3,6,12,18$ & 12,18 & Yes & & $\begin{array}{l}\text { Dopamine } \\
D_{1} / D_{5} \\
\text { agonists } \\
\text { rescued } \\
\text { deficits }\end{array}$ & & Yes \\
\hline $\begin{array}{l}\text { Barnes et al. } \\
\text { (1991) }\end{array}$ & Fisher 344 rat & 6,27 & 27 & Yes & & & & Yes \\
\hline $\begin{array}{l}\text { Barrett et al. } \\
\text { (2009) }\end{array}$ & $\begin{array}{l}\text { Sprague- } \\
\text { Dawley, dark } \\
\text { agouti rat }\end{array}$ & $\begin{array}{l}6,11,14 \\
17,20,26\end{array}$ & $\begin{array}{l}\text { Agouti: 11+; } \\
\text { Sprague- } \\
\text { Dawley: 14+ }\end{array}$ & Yes & $\begin{array}{l}\text { Sprague-Dawley > dark } \\
\text { agouti }\end{array}$ & & & Yes \\
\hline $\begin{array}{l}\text { Harrison } \\
\text { et al. } \\
(2009 a, b)\end{array}$ & C57BL/6 & 2 & & & $\begin{array}{l}\text { Inc corticosteronenot } \\
\text { correlated with } \\
\text { performance }\end{array}$ & & & \\
\hline $\begin{array}{l}\text { King and } \\
\text { Arendash } \\
\text { (2002) }\end{array}$ & $\begin{array}{l}\text { Tg2576, } \\
\text { C57BL/6 }\end{array}$ & $3,14,19$ & C57: $14<3,19$ & Yes & $\begin{array}{l}\text { Aged B6 may not show } \\
\text { deficits in spatial } \\
\text { memory }\end{array}$ & & & No \\
\hline $\begin{array}{l}\text { Patil et al. } \\
\text { (2009) }\end{array}$ & C57BL/6, CD1 & 3 & & & $\mathrm{C} 57>\mathrm{CD} 1$ & & & \\
\hline
\end{tabular}


yet been investigated, so it is premature to declare the test as purely hippocampal (Criterion 7). The Barnes maze satisfies four of the criteria for the evaluation of age-sensitivity. Additional research is needed to examine the impact of cognition-enhancing drugs, the influence of mouse strain, and the contribution of the cerebellum to the task.

\section{ROTOROD}

Rotorod is a task assessing balance, coordination, and motor learning (Figure 3).

\section{Neural substrates}

The cerebellum is essential for sustaining rotorod performance (Lalonde et al., 1995; Lalonde and Strazielle, 2003b). Studies conducted in mice with mutations affecting cerebellar Purkinje cells implicate the cerebellum as essential for the task, but the degree to which cerebellar atrophy affects the rotorod is unclear. Lurcher mice, a strain with degenerated cerebellar granule and Purkinje cells, are able to learn the rotorod task, but show shorter latencies to fall than control mice (Lalonde et al., 1995). Two other mutant strains, staggerer (massive degeneration of granule and Purkinje cells) and hot-foot (defective innervation of Purkinje cells but not massive degeneration) showed shorter latencies to fall than the Lurcher mice, suggesting differences in rotorod performance from different types of cerebellar atrophy. Other research suggests that the cerebellar cortex is critical for the coordinated whole body movements needed to perform on the rotorod but not for stationary motor tasks such as vertical and tilted grids and a coat-hanger task (Le Marec and Lalonde, 1997). A threshold for the number of Purkinje cells necessary to show evidence of motor deficits has been proposed through the performance of chimeric (individual

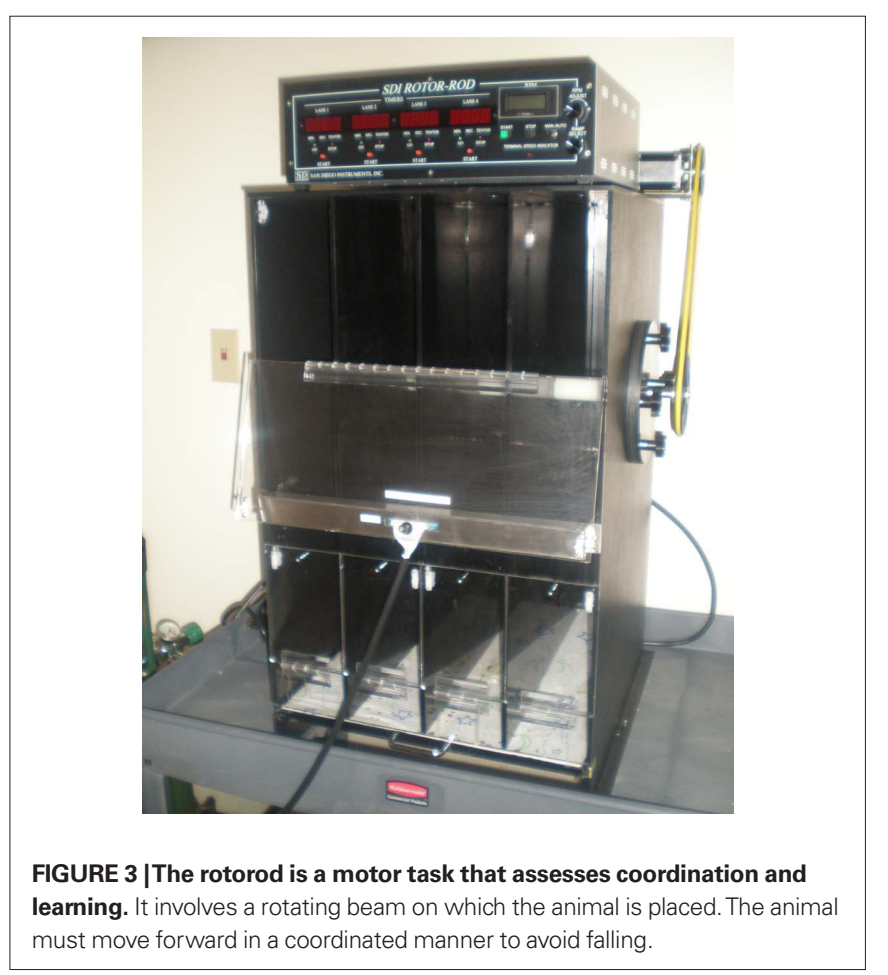

animals in the litter have different numbers of Purkinje cells) mice (Martin et al., 2003). Performance on the rotorod task is clearly linked to the underlying cerebellar structure.

\section{Age-related deficits}

The rotorod is widely used to test motor coordination and learning at various ages from as young as 19-days old (Bearzatto et al., 2005), through adulthood (Thouvarecq et al., 2001) and into old age (Ingram et al., 1987). Older mice show impairment on both the standard and accelerating rotorod paradigms, and age deficits are also seen in older rats (Bickford, 1995; Shukitt-Hale et al., 1998). Despite the general finding that age-related deficits are observed on this test, there remains considerable disagreement about the age at which deficits become apparent. A number of studies have reported that deficits appear around 12-13 months in C57BL/6 mice (Thouvarecq et al., 2001; Vogel et al., 2002), though deficits have been reported as early as 7 months (Fetsko et al., 2005; Serradj and Jamon, 2007). Depending on the study, paradigm, and species, deficits become progressively worse with older age, though this is not reported in all cases.

\section{AGE SENSITIVITY}

The rotorod is useful in detecting age-related differences in cerebellar function, however, different species of mouse perform at different levels, and strain differences do not remain consistent throughout development (Crawley et al., 1997; Bearzatto et al., 2005). For example, C57BL/6 mice outperformed 129/Sv mice at multiple ages tested and showed a significant decrease in motor learning beginning at 7 months, which declined further at 13 months (Serradj and Jamon, 2007). 129/Sv mice showed no real improvements in motor learning from 1 to 3 months and showed a slight (but non-significant) decrease at the older ages. Both of these strains are utilized in the creation of mutant mouse strains, including models of accelerated aging and age-related disease. Strain differences in rotorod performance have been recognized (Logue et al., 1997b; Contet et al., 2001; Voikar et al., 2001; Serradj and Jamon, 2007), and different strains of mice show different age-related changes in performance (Ingram and Jucker, 1999). When considering the utility of the rotorod in assessing age-related changes in motor learning, strain differences could present a problem of interpretation - motor impairment may vary at the same age in testing due to the relative genetic contributions of the strain(s) involved.

An additional issue that affects the sensitivity of the rotorod is that performance requires a number of components - balance, coordination, motor skills, and learning skills - that make interpretation of results difficult (Serradj and Jamon, 2007). The current paradigm cannot identify the source of deficits; any one (or combination) of the abilities could be responsible. Thouvarecq et al. (2001) have argued that the rotorod measures motor learning and is either insensitive to or does not measure motor skills. Body weight may pose a particular problem to the age sensitivity of the rotorod, as some studies have shown that it is negatively correlated with performance (Ingram, 1983). Weight could confound conclusions about age-related changes in the cerebellum contributing to deficits seen in performance, though this correlation has not always been replicated (Ingram et al., 1987). 
The rotorod satisfies some, but not all, of the criteria to evaluate age-sensitivity. The test is able to detect age-related deficits in motor learning in both rats and mice (Criteria 1 and 5), but has not been tested in other species (see Table 3). Performance may be confounded by weight and could be accounted for by a number of components of motor function that cannot be differentiated (Criterion 2). Any stress caused by running on the rotating beam is not sufficient to affect older animals and prohibit completion of the task (Criterion 3). A large body of lesion and mutant strain research has confirmed that the rotorod relies on the intact cerebellum and can be considered a purely cerebellar task (Criteria 4 and 7). As for the sixth criterion, drugs that improve learning and memory in clinical trials have not been applied to the rotorod, though animals modeling the massive loss of dopaminergic neurons seen in Parkinson's dis- ease show improved performance when given coenzyme $\mathrm{Q}_{10}$ (Somayajulu-Nitu et al., 2009) or selective dopamine $\mathrm{D}_{3}$ receptor antagonists (Mela et al., 2010).

\section{EYEBLINK CLASSICAL CONDITIONING}

Eyeblink classical conditioning is a test of associative learning in which a neutral stimulus is paired with a blink reflex-emitting stimulus until the neutral stimulus elicits the reflex or a partial reflex (Figure 4).

\section{Neural substrates}

The circuitry required to support the formation of conditioned responses in EBCC has been almost entirely defined and parallels exist in neurobiology and behavior across a number of mammalian species (Woodruff-Pak and Steinmetz, 2000a,b; Christian

\section{Table 3 | Rotorod: age sensitivity.}

\begin{tabular}{|c|c|c|c|c|c|c|c|c|}
\hline Study & $\begin{array}{l}\text { Species/ } \\
\text { strain }\end{array}$ & $\begin{array}{l}\text { Age } \\
\text { (months) }\end{array}$ & $\begin{array}{l}\text { Age } \\
\text { deficits } \\
\text { (months) }\end{array}$ & $\begin{array}{l}\text { Mirror } \\
\text { lesions in } \\
\text { young }\end{array}$ & $\begin{array}{l}\text { Confounds/ } \\
\text { strain differences }\end{array}$ & $\begin{array}{l}\text { Effect of } \\
\text { cognition- } \\
\text { enhancing drugs }\end{array}$ & $\begin{array}{l}\text { Cerebellum- } \\
\text { sensitive }\end{array}$ & $\begin{array}{l}\text { Hippocampus- } \\
\text { sensitive }\end{array}$ \\
\hline $\begin{array}{l}\text { Fetsko } \\
\text { et al. (2005) }\end{array}$ & C57BL/6 & $\begin{array}{l}1,3,7,10 \\
12,18,23\end{array}$ & 7 & Yes & & & Yes & \\
\hline $\begin{array}{l}\text { Ingram } \\
\text { et al. (1987) }\end{array}$ & C3B10RF & $\begin{array}{l}11-15 \\
31-35\end{array}$ & $31-35$ & Yes & Weight confound & & Yes & \\
\hline $\begin{array}{l}\text { Mela et al. } \\
\text { (2010) }\end{array}$ & $\begin{array}{l}\text { Sprague- } \\
\text { Dawley } \\
\text { rat }\end{array}$ & & & & & $\begin{array}{l}\text { Dopamine } D_{3} \\
\text { agonist rescues } \\
\text { deficits in } \\
\text { Parkinson's model }\end{array}$ & & \\
\hline $\begin{array}{l}\text { Serradj and } \\
\text { Jamon } \\
(2007)\end{array}$ & $\begin{array}{l}\text { 129/Sv } \\
\text { and } \\
\text { C57BL/6 }\end{array}$ & $1,3,7,13$ & $\begin{array}{l}\text { C57-7; } \\
129 \\
\text { - None }\end{array}$ & Yes & $\begin{array}{l}\text { C57 > } 129 \text { at all } \\
\text { ages; } 129 \text { poor } \\
\text { learners }\end{array}$ & & Yes & \\
\hline $\begin{array}{l}\text { Shukitt- } \\
\text { Hale et al. } \\
\text { (1998) }\end{array}$ & $\begin{array}{l}\text { Fisher } \\
344 \text { rat }\end{array}$ & $\begin{array}{l}6,12,15 \\
18,22\end{array}$ & $12+$ & Yes & & & Yes & \\
\hline $\begin{array}{l}\text { Vogel et al. } \\
\text { (2002) }\end{array}$ & C57BL/6 & $4,12,18$ & 12,18 & Yes & & & Yes & \\
\hline
\end{tabular}




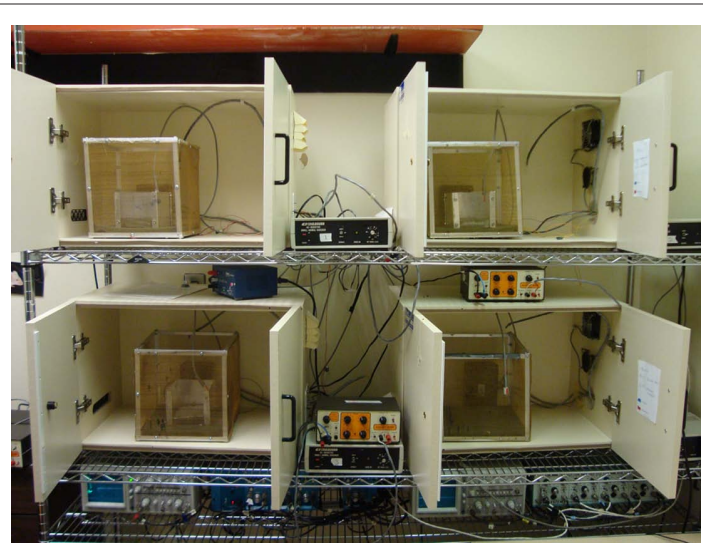

FIGURE 4 | Eyeblink classical conditioning is a form of associative learning in which a previously neutral stimulus such as a tone or light (CS) is presented briefly before a blink-inducing unconditioned stimulus (US), such as a puff of air to the eye or a shock to the muscles around the eye. In the standard delay paradigm, the CS and US overlap, and coterminate. After repeated pairings, the animal learns to associate the stimuli and begins to blink to the CS before the onset of the US - a behavior termed conditioned response (CR).

and Thompson 2003). The essential site of plasticity is the interpositus nucleus of the cerebellum, ipsilateral to the conditioned eye (Thompson, 1986). Information about the US carried in the climbing fibers projecting from the inferior olive and the CS carried by the mossy fibers from the pontine nucleus converge on the Purkinje cells of the cerebellar cortex and the interpositus nucleus leading to the plasticity that supports learning. Purkinje cells, which are large, inhibitory neurons, provide the only efferent input to the interpositus nucleus from the cerebellar cortex and affect the rate of conditioning, though they are not essential for the formation of a CR (Christian and Thompson, 2003; Woodruff-Pak and Disterhoft, 2008). Purkinje cell degeneration ( $p c d)$ mice that lack any output from the cerebellar cortex to deep nuclei are profoundly impaired in acquisition of delay EBCC (Chen et al., 1996; Woodruff-Pak and Disterhoft, 2008), though they are still able to acquire some CRs. Lesions to the interpositus nucleus, however, completely abolish the CR (Woodruff-Pak et al., 1985; Thompson, 1986; Chen et al., 1999). The hippocampus is not required for delay conditioning, though it can modulate the rate of conditioning (Berger et al., 1976, 1983; Thompson et al., 1983; Christian and Thompson, 2003). Lesions to the hippocampus do not impair acquisition of CRs (Schmaltz and Theios, 1972; Solomon and Moore, 1975), whereas functional disruption causes impairment (Solomon et al., 1983). Finally, a cerebellar cortical LTD-like process is required to support normal delay conditioning (Ito, 1989; Linden and Connor, 1995; Christian and Thompson, 2003; Woodruff-Pak and Disterhoft, 2008).

Trace eyeblink conditioning is distinct from delay conditioning in that the CS and US are separated by a stimulus free interval. The essential site of plasticity is still the interpositus nucleus (WoodruffPak et al., 1985), though to process the stimulus free trace period, forebrain areas such as the hippocampus (Kim et al., 1995; Weiss et al., 1999; Tseng et al., 2004) and prefrontal cortex (KronforstCollins and Disterhoft, 1998; Weible et al., 2000) are necessary. Scopolamine administration at doses low enough to have little effect on delay conditioning prevent acquisition of the trace CR, whereas lesions to the hippocampus after training abolish the CR (Kaneko and Thompson, 1997), though this retrograde amnesia is timelimited (Kim et al., 1995). Initial work in rabbits suggested that the cerebellar cortex is involved in trace conditioning (Woodruff-Pak et al., 1985), though studies using transgenic mice demonstrated that trace conditioning remained normal despite disruptions of the cerebellar cortex (Kishimoto et al., 2001a,b, 2002). Forebrain structures bypass the cerebellar cortex in trace conditioning by bridging the temporal gap through pontine-cerebellar nuclear connections (Woodruff-Pak and Disterhoft, 2008). Further evidence that the cerebellar cortex may not be necessary for trace conditioning comes from a study of homozygous pcd mice (Brown et al., 2010). These mice, with a complete loss of cerebellar cortical Purkinje cells were not impaired on trace conditioning. The cerebellar cortex does not appear to be engaged in trace conditioning, although it supports a normal rate of acquisition in delay eyeblink conditioning.

\section{Age-related deficits}

The ability to perform EBCC declines with age. This result has been replicated in a variety of mammalian species such as humans (Solomon et al., 1989; Woodruff-Pak and Thompson, 1988), rabbits (Thompson et al., 1996; Woodruff-Pak et al., 2001), mice (Woodruff-Pak, 2006), and cats (Harrison and Buchwald 1983). In humans, deficits begin to emerge in the decade of the 40 s, performance declines significantly in the 50s, and remains relatively stable through the 80s (Woodruff-Pak and Thompson, 1988; WoodruffPak and Jaeger, 1998).

In rabbits, the developmental trajectory of age deficits mirrors that of humans, with differences seen first around middle age. Woodruff-Pak et al. (1987) reported increases in the number of trials to reach criterion in older rabbits ( 30 and 45 months) compared to younger ( 3 month) in the trace paradigm, though not all older animals were impaired. The estimated life expectancy for a rabbit is about 8 years (Fox, 1980) and based on declines seen in reproductive capacity around 18-24 months, the impaired older rabbits would be comparable to humans aged $40-50$ years - precisely the age range identified by Woodruff-Pak and Thompson (1988).

Declines in reproductive capacity (decrease in litter size) in the mouse begin around 8 months (Biggers et al., 1962; Pritchett and Taft, 2006), suggesting that at this age mice approximate rabbits 18 -months-old and middle-aged humans. In the 250-ms delay paradigm, mice aged 9, 12, and 18 months were impaired relative to mice aged 4 months, taking longer to develop CRs (Vogel et al., 2002). These results were not entirely supported in another study (Kishimoto et al., 2001c) that compared the same strain of mouse (C57BL/6) in a very similar paradigm (252-ms delay). These authors reported impaired EBCC at the oldest age tested (21-22 months) but not at middle age (11-12 months). Other studies have shown no significant differences in performance in C57BL/6 mice at 12 months (Woodruff-Pak, 2006) in the 500-ms delay paradigm, though conclusions regarding performance of C57BL/6 mice may be confounded by age-related loss of hearing around middle age (Ouagazzal et al., 2006). Auditory acuity remains relatively intact over the life span in CBA mice (Ohlemiller, 2009). We recently reported that CBA mice aged 24 months were significantly impaired in the 500-ms delay paradigm relative to 4 -month-old mice (Woodruff-Pak et al., 
2010). In addition, unbiased stereological estimation of Purkinje neurons showed age-related decreases at both 18 and 24 months. Other research has confirmed the age-related loss of Purkinje cells in mice (Woodruff-Pak, 2006) and rabbits (Woodruff-Pak et al., 1990) and the relation to age deficits in EBCC.

\section{Age sensitivity}

The age sensitivity of EBCC is apparent in its wide-ranging applicability, where age-related deficits have been reported in a number of species including mice (Kishimoto et al., 2001c; Vogel et al., 2002; Woodruff-Pak, 2006; Woodruff-Pak et al., 2010), rats (Weiss and Thompson, 1992), rabbits (Woodruff-Pak et al., 1987, 2007a; Woodruff-Pak, 1988), and humans (Woodruff-Pak and Thompson, 1988; Solomon et al., 1989; Woodruff-Pak and Jaeger, 1998). Due to the extremely well-studied neural substrates, a number of crossspecies commonalities have been reported in terms of neurobiology and behavioral performance. In addition, EBCC performance deficits with age have been associated with Purkinje cells, one of the few neurons in the CNS that show significant loss with normal aging (Larsen et al., 2000; Anderson et al., 2003; Woodruff-Pak, 2006; Woodruff-Pak et al., 2010), thus providing an identifiable neural substrate for age deficits. The advantage of EBCC over many of the tests considered here is that it can be accomplished in human subjects, therefore providing a translational utility across human and non-human species. Classical fear conditioning can be conducted in human populations (Alvarez et al., 2008), although some investigators are reluctant to employ a paradigm that requires the application of shock to humans. A parallel assessment for spatial learning and memory in rodents (Morris water maze and Barnes maze) that uses virtual reality has been elaborated recently and tested in children and older adults (Haley and Raber, 2011). With EBCC, the power of conclusions regarding age-related performance deficits in humans is only strengthened by the similarity in performance across species. Finally, this paradigm provides the ability to take advantage of a number of species-specific experimental designs, including the short life span and potential for genetically altered mice, as well as the larger brain size and better adaptability to restraint of rabbits (Woodruff-Pak, 1988).

Woodruff-Pak (1990) reviewed the classically conditioned nictitating-membrane response in rabbits as a model system for studying learning, memory and aging using criteria similar to those suggested in this review to examine the sensitivity of behavioral tests in the aging mouse. It was argued that data to support a criterion similar to Criterion 6 here, that pharmacological agents would ameliorate age-related deficits in performance, were promising but still preliminary. In the years since the review by Woodruff-Pak (1990), several studies have administered cognition-enhancing drugs such as memantine, galantamine, and donepezil (Woodruff-Pak et al., 2001, 2007b; Weible et al., 2004), as well as nefiracetam and physostigmine (Woodruff-Pak and Li, 1994; Woodruff-Pak et al., 2004) to older rabbits, and many of these drugs have been successful in ameliorating differences in EBCC performance. The rabbit version of EBCC engages both structures of interest (Criterion 7), since the cerebellum is essential and the hippocampus plays a modulatory role in the delay paradigm and is essential in the trace paradigm.

Though the rabbit version of EBCC satisfies the criteria identified in this review, the focus is on aging in the mouse (see Table 4). Given that the neural substrates of EBCC are conserved across many species, the test partially satisfies the fifth criterion of behavioral parallels across many species, though strain differences may contribute to differential results. In the case of C57BL/6 mice, agerelated hearing loss may bias interpretation of results (Criteria 2 and 5). Age deficits have been reliably reported in other strains of mice that do not suffer from hearing loss, and both genetic and experimental lesions to the cerebellum in young mice cause deficits similar to those of older animals (Criteria 1 and 4). The shock US is relatively mild and no food restriction is required (Criterion $3)$. In contrast to rabbit studies, cognition-enhancing drugs have rarely been investigated in older mice (Criterion 6). Drug-induced deficits in EBCC can be rescued by the administration of nicotinic receptor agonists (Rodriguez-Moreno et al., 2006), but the effect of drugs on normal aged mice requires further exploration. Finally, EBCC in the mouse, as in the rabbit, cannot be considered a purely cerebellar task (Criterion 7).

\section{FEAR CONDITIONING}

Classical conditioning of fear is a paradigm that has received extensive study in recent years (Figure 5).

\section{Neural substrates}

The primary dependent measure of fear conditioning is freezing, which is normally defined as the absence of movement apart from respiration (Fanselow, 1990). A conditioned-fear response (freezing) can be elicited by either the originally neutral tone CS (cued fear) or the environment (context fear) in which the US was previously presented to the animal. This form of associative learning is rapid and robust, and the neural substrates have been fairly well defined, thus making this paradigm particularly attractive to researchers. Another benefit of fear conditioning is that it measures both hippocampus-dependent and -independent learning (Kim and Fanselow, 1992; Phillips and LeDoux, 1992; Rudy, 1993; Gerlai, 1998). Learning to associate the context with the US depends on the hippocampus while the association between the auditory CS and the US does not (Kim and Fanselow, 1992; Phillips and LeDoux, 1992; Gerlai, 1998). Both pharmacological (Logue et al., 1997a; Gerlai, 1998) and electrolytic (Kim and Fanselow, 1992; Phillips and LeDoux, 1992) lesions to the hippocampus result in a reduced amount of freezing to the context compared to nonlesioned controls.

The hippocampus is the essential site for contextual fear conditioning (Frankland et al., 1998; Maren et al., 1998). The ventral hippocampus may be the necessary substrate as excitotoxic lesions impair conditioning when administered to the ventral (Selden et al., 1991; Phillips and LeDoux, 1992) but not the dorsal hippocampus (Maren et al., 1997). Impaired context conditioning due to ventral hippocampus lesions may be the result of disrupting inputs to the nucleus accumbens, which would alter the exploratory behavior that is essential for normally exploring the environment (Maren, 1999), or by damaging the amygdala (Anagnostaras et al., 2001). Axon-sparing neurotoxic lesions may be the most appropriate because electrolytic lesions can damage fibers passing through the hippocampus (Maren, 1999). The other essential neural substrate required for cued fear conditioning is the amygdala, the site where the formation of the CS-US association occurs (Phillips and LeDoux, 1992). 
Table 4 | Eyeblink classical conditioning: age sensitivity.

\begin{tabular}{|c|c|c|c|c|c|c|c|c|}
\hline Study & $\begin{array}{l}\text { Species/ } \\
\text { strain }\end{array}$ & $\begin{array}{l}\text { Age } \\
\text { (months) }\end{array}$ & $\begin{array}{l}\text { Age deficits } \\
\text { (months) }\end{array}$ & $\begin{array}{l}\text { Mirror lesions } \\
\text { in young }\end{array}$ & $\begin{array}{l}\text { Confounds/ } \\
\text { strain } \\
\text { differences }\end{array}$ & $\begin{array}{l}\text { Effect of } \\
\text { cognition- } \\
\text { enhancing drugs }\end{array}$ & $\begin{array}{l}\text { Cerebellum- } \\
\text { sensitive }\end{array}$ & $\begin{array}{l}\text { Hippocampus- } \\
\text { sensitive }\end{array}$ \\
\hline $\begin{array}{l}\text { Kishimoto et al. } \\
\text { (2001c) }\end{array}$ & C57BL/6 & $\begin{array}{l}2,11-12 \\
21-22\end{array}$ & $\begin{array}{l}\text { Delay: } 21-22 ; \\
\text { Trace: } 11-12+\end{array}$ & Yes & $\begin{array}{l}\text { Age-related } \\
\text { hearing loss }\end{array}$ & & Yes & Yes \\
\hline $\begin{array}{l}\text { Vogel et al. } \\
(2002)\end{array}$ & C57BL/6 & $\begin{array}{l}4,9,12 \\
18\end{array}$ & $9+$ & Yes & $\begin{array}{l}\text { Age-related } \\
\text { hearing loss }\end{array}$ & & Yes & \\
\hline $\begin{array}{l}\text { Weible et al. } \\
\text { (2004) }\end{array}$ & Rabbit & $\begin{array}{l}2-3 \\
30-33\end{array}$ & $30-33$ & Yes & & $\begin{array}{l}\text { Galantamine } \\
\text { rescues deficits }\end{array}$ & & Yes \\
\hline $\begin{array}{l}\text { Woodruff-Pak } \\
\text { (2006) }\end{array}$ & C57BL/6 & $\begin{array}{l}4,8,12 \\
18,24\end{array}$ & $18+$ & Yes & $\begin{array}{l}\text { Age-related } \\
\text { hearing loss }\end{array}$ & & Yes & \\
\hline $\begin{array}{l}\text { Woodruff-Pak } \\
\text { et al. (2010) }\end{array}$ & CBA & $\begin{array}{l}4,8,12 \\
18,24\end{array}$ & 24 & Yes & & & Yes & \\
\hline $\begin{array}{l}\text { Woodruff-Pak } \\
\text { et al. }(2007 a, b)\end{array}$ & Rabbit & 26 & $\begin{array}{l}\text { Untreated } \\
\text { rabbits } \\
\text { impaired in } \\
\text { acquisition }\end{array}$ & Yes & & $\begin{array}{l}\text { Galantamine } \\
\text { improves } \\
\text { acquisition }\end{array}$ & & Yes \\
\hline
\end{tabular}

Species is mouse unless otherwise specified. $C 57=C 57 B L / 6$.

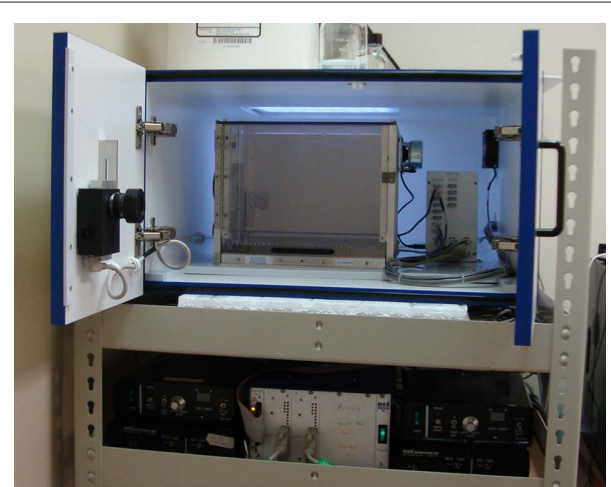

FIGURE 5 | Fear conditioning is a form of associative learning in which a previously neutral conditioned stimulus (CS), such as a tone, is paired with an aversive unconditioned stimulus (US), usually a foot shock. Through this pairing, the CS comes to elicit responses characteristically associated with the US.

At a neurotransmitter level, the cholinergic system has been implicated in context fear conditioning (Gould and Wehner, 1999; Gale et al., 2001; Feiro and Gould, 2005). Lesions of the nucleus basalis magnocellularis, which contains large cholinergic neurons that project to the neocortex, disrupts context but spares cued fear (Stoehr and Wenk, 1995). Scopolamine, a muscarinic cholinergic receptor $(\mathrm{mAChR})$ antagonist, administered either systemically (Feiro and Gould, 2005) or directly into the dorsal hippocampus (Gale et al., 2001) impairs context but not cued conditioning. Administration of nicotine improves context learning while mecamylamine, a nicotinic cholinergic receptor ( $\mathrm{AAChR}$ ) antagonist, prevents the nicotine-induced improvements in context learning (Gould and Wehner, 1999). The administration of only mecamylamine did not alter contextual fear conditioning, which suggests that $\mathrm{nAChR}$ activation is not required for context learning but instead can serve a modulatory role. Additionally, nicotinic and muscarinic receptors interact to contribute to the learning that takes place in fear conditioning, as co-administration of $\mathrm{nAChR}$ and $\mathrm{mAChR}$ antagonists disrupts both cued and context fear learning, though the effects of this interaction may differ across the life span (Feiro and Gould, 2005).

\section{Age deficits}

Generally, aged rats and mice do not differ in the ability to freeze to an aversive stimulus, nor do they show deficits in the ability to form CS-US associations compared to younger animals (Doyere 
et al., 2000; Gould and Feiro, 2005). One study reported that 22-month-old Wistar rats showed more freezing to the context than younger ( 7 month) animals, which may have been related to an increase in emotionality in the older rats (Doyere et al., 2000). More often reported is that older animals are not impaired on context fear, with the exception of long-term retention intervals of 20-60 days (Stoehr and Wenk, 1995; Oler and Markus, 1998; Houston et al., 1999; Mesches et al., 2004). Deficits in contextual fear have been reported at a 24 -h retention interval for 11 month C57BL/6N compared to 8-month mice (Liu et al., 2003). Longer retention intervals also affect age-related abilities to retain cued fear information (Gould and Feiro, 2005).

In trace fear conditioning, a temporal gap exists between the presentation of the CS and the US. In this case, subsequent freezing to the tone CS requires the hippocampus to process the trace, or temporal gap, between the CS and US presentations (McEchron et al., 1998; Huerta et al., 2000; Villarreal et al., 2004). Older rats (22-24 month) are impaired in trace cued fear relative to younger (2-4 month) animals, whereas performance is equal for delay contextual fear conditioning (Villarreal et al., 2004). Contrasting studies with different strains of rats have shown no age differences in freezing among 2,5 , and 12 month animals in a trace fear conditioning paradigm (Cuppini et al., 2006). In mice tested at a 24-h retention interval, deficits in freezing to the context were seen in older ( 8 month) relative to younger animals (2, 4 month), whereas cued fear was not affected by age (Kaczorowski and Disterhoft, 2009). Thus, strain and paradigm differences can affect the ability of the fear conditioning task to detect age differences in both the trace and delay paradigms.

\section{Age sensitivity}

Of all the tests described in this paper, delay cued and contextual fear conditioning are perhaps the least sensitive to age. Whereas the Barnes maze or MWM show behavioral deficits in both the acquisition and retention of spatial memory, delay fear conditioning is acquired normally in rodents across the life span. Age deficits are only apparent at long retention intervals $(48+\mathrm{h})$. Decreases in neurogenesis in the dentate gyrus that accompany aging are not detected by fear conditioning, as no differences in cued or context freezing were seen in older rats tested on the trace paradigm even though they had reduced proliferation and new cell survival (Cuppini et al., 2006). Trace fear conditioning may be more sensitive to aging than delay fear conditioning as deficits in retention of cued and context fear are more consistently reported at earlier retest intervals.

Another potential drawback of the context fear paradigm is that electrolytic lesions to the hippocampus can increase motor activity, which invalidates the freezing response as a measure and makes interpretation difficult (Maren et al., 1998; Gale et al., 2001). Increased motor activity is not seen in pharmacological lesions of the hippocampus, so hyperactivity may not be a function of damage to the hippocampus but rather damage to the fibers of passage (Gale et al., 2001). In addition, Maren et al. (1998) reported no significant correlation between motor activity and context freezing in hippocampal lesioned rats, suggesting that a motor explanation for freezing deficits seems unlikely.

That lesions to the hippocampus differentially affect performance on the MWM and fear conditioning suggests that the two tasks require the hippocampus to a different extent. Since fear conditioning incorporates both a simpler dependent measure (freezing vs. motor control in swimming) and relies on more sensory systems (incorporating tactile, olfactory, and auditory stimuli into the context representation), it may be more difficult to see age-related differences in this task. In addition, context fear conditioning may be supported by other, non-hippocampal systems in certain situations (Owen et al., 1997; Gerlai, 1998; Gale et al., 2001). For example, lesions to the dorsal hippocampus prior to training reduce the amount of context freezing (Frankland et al., 1998; Gerlai, 1998) but do not abolish the ability to learn. Lesioned animals still show some freezing to the context, but the amount is reduced compared to sham lesioned controls. These results suggest a compensatory mechanism may be operating in the absence of the hippocampus that can allow the formation of the context-shock association. Normally, the hippocampus is involved in the formation of a unified, polymodal representation of cues in the training environment (Sutherland and Rudy, 1989; Frankland et al., 1998), which is then associated with the shock US (Phillips and LeDoux, 1992). Both rats and mice can represent the context through a single-cue strategy, which does not rely on the hippocampus and is normally suppressed (Logue et al., 1997a; Frankland et al., 1998). A single-cue strategy involves associating one or two salient cues of the context, rather than a unified representation, with the US shock. Context freezing is reduced compared to animals using a hippocampus-based strategy, suggesting that the non-hippocampal system may be less efficient, but still allow for learning.

With the exception of long-term retention, delay contextual fear conditioning does not generally reveal age-related performance deficits (see Table 5). Trace conditioning may be more sensitive to age differences (Criterion 1). Aged animals are able to perform the task, which suggests that the shock used is not too intense as a stressor (Criterion 3). There are several confounds that could account for differences in freezing to the context, including increased motor activity after electrolytic lesions to the hippocampus, strain differences and a secondary neural substrate that can support conditioning (Criteria 2 and 5). This alternate system that involves the peri-and postrhinal cortices precludes describing contextual fear conditioning as a purely hippocampal task (Criterion 7). In addition, the complicated results of lesion studies does not yield a unified behavioral response to compare to aged animals, though lesioned animals tend to show larger deficits than aged animals (Criterion 4). Since age deficits are not generally reported in contextual fear, the impact of cognition-enhancing drugs is undetermined (Criterion 6). Gould and Feiro (2005) reported that galantamine administered to aged $\mathrm{C} 57 \mathrm{BL} / 6$ mice reversed deficits in retention of cued fear, whereas no deficits were reported in context fear. Thus, contextual fear conditioning does not appear to satisfy any of the criteria to evaluate age-sensitivity. A modification of the context fear paradigm, the context pre-exposure facilitation effect (CPFE), affords increased sensitivity to hippocampal disruption and the potential application to aging studies.

\section{CONTEXT PRE-EXPOSURE FACILITATION EFFECT Neural substrates}

When a rodent is placed into a context and a shock is delivered within a short amount of time $(2-3 \mathrm{~s})$ the animal will show little to no fear to the context when tested later (Blanchard et al., 
Table 5 | Fear conditioning: age sensitivity.

\begin{tabular}{|c|c|c|c|c|c|c|c|c|}
\hline Study & $\begin{array}{l}\text { Species/ } \\
\text { strain }\end{array}$ & $\begin{array}{l}\text { Age } \\
\text { (months) }\end{array}$ & Age deficits & $\begin{array}{l}\text { Mirror } \\
\text { lesions in } \\
\text { young }\end{array}$ & $\begin{array}{l}\text { Confounds/ } \\
\text { strain } \\
\text { differences }\end{array}$ & $\begin{array}{l}\text { Effect of } \\
\text { cognition- } \\
\text { enhancing drugs }\end{array}$ & $\begin{array}{l}\text { Cerebellum- } \\
\text { sensitive }\end{array}$ & $\begin{array}{l}\text { Hippocampus- } \\
\text { sensitive }\end{array}$ \\
\hline $\begin{array}{l}\text { Doyere et al. } \\
(2000)\end{array}$ & Wistar rat & 7,22 & $\begin{array}{l}22 \text { months } \\
\text { froze more to } \\
\text { context }\end{array}$ & No & & & & No \\
\hline $\begin{array}{l}\text { Feiro and } \\
\text { Gould (2005) }\end{array}$ & C57BL/6 & $2-3,19-20$ & $\begin{array}{l}19-20 \text { months } \\
\text { to CS at } 48+h \\
\text { retention }\end{array}$ & No & & & & Yes \\
\hline Gerlai (1998) & $\begin{array}{l}\text { C57BL/6, } \\
\text { DBA/2 }\end{array}$ & $3-4$ & Not rested & $\begin{array}{l}\text { Lesions } \\
\text { partially } \\
\text { impair }\end{array}$ & $\begin{array}{l}\text { DBA more } \\
\text { sensitive to } \\
\text { shock; C57 froze } \\
\text { more to context } \\
\text { and tone CS }\end{array}$ & & & No \\
\hline $\begin{array}{l}\text { Gould and } \\
\text { Feiro (2005) }\end{array}$ & C57BL/6 & $2-3,19-20$ & $\begin{array}{l}19-20 \text { to } C S \text { at } \\
48+h \\
\text { retention }\end{array}$ & No & & $\begin{array}{l}\text { Galantamine- } \\
\text { rescued deficits }\end{array}$ & & No \\
\hline $\begin{array}{l}\text { Gould and } \\
\text { Wehner } \\
\text { (1999) }\end{array}$ & C57BL/6 & $2-3$ & & & & $\begin{array}{l}\text { Nicotine } \\
\text { enhances context } \\
\text { learning }\end{array}$ & & Yes \\
\hline $\begin{array}{l}\text { Houston et al. } \\
\text { (1999) }\end{array}$ & $\begin{array}{l}\text { Fisher } 344 \\
\text { rat }\end{array}$ & $3,9,27$ & $\begin{array}{l}27 \text { months to } \\
\text { context in } \\
20-60 \text { day } \\
\text { retention }\end{array}$ & Yes & & & & Yes \\
\hline $\begin{array}{l}\text { Mesches } \\
\text { et al. (2004) }\end{array}$ & $\begin{array}{l}\text { Fisher } 344 \\
\text { rat }\end{array}$ & 6,18 & $\begin{array}{l}18 \text { months to } \\
\text { context in } \\
\text { 48-h retention }\end{array}$ & Yes & & & & Yes \\
\hline $\begin{array}{l}\text { Oler and } \\
\text { Markus } \\
\text { (1998) }\end{array}$ & $\begin{array}{l}\text { Fisher } 344 \\
\text { rat }\end{array}$ & $4,10,23$ & $\begin{array}{l}23 \text { months to } \\
\text { context in } \\
\text { 52-day } \\
\text { retention }\end{array}$ & Yes & & & & Yes \\
\hline $\begin{array}{l}\text { Owen et al. } \\
\text { (1997) }\end{array}$ & $\begin{array}{l}12 \text { inbred } \\
\text { and seven } \\
\text { hybrid } \\
\text { strains }\end{array}$ & $2-3$ & & & $\begin{array}{l}\text { Good: C57, 129, } \\
\text { hybrids; Poor: } \\
\text { FVB, DBA, Bub, } \\
\text { C3H }\end{array}$ & & & \\
\hline $\begin{array}{l}\text { Paylor et al. } \\
\text { (1994) }\end{array}$ & $\begin{array}{l}\text { C57BL/6, } \\
\text { DBA/2 }\end{array}$ & $3-4$ & & & $\begin{array}{l}\text { C57 froze more } \\
\text { to context }\end{array}$ & & & Yes \\
\hline $\begin{array}{l}\text { Stoehr and } \\
\text { Wenk (1995) }\end{array}$ & $\begin{array}{l}\text { Fisher } 344 \\
\text { rat }\end{array}$ & $3,9,24$ & 24 months & Yes & & & & Yes \\
\hline $\begin{array}{l}\text { Villarreal et al. } \\
\text { (2004) }\end{array}$ & $\begin{array}{l}\text { Fisher } 344 \\
\text { rat }\end{array}$ & $2-4,22-24$ & $\begin{array}{l}22-24 \text { months } \\
\text { impaired on } \\
\text { trace cued }\end{array}$ & Yes & $\begin{array}{l}\text { No age deficits in } \\
\text { delay paradigm }\end{array}$ & & & Yes \\
\hline
\end{tabular}

Species is mouse unless otherwise specified. C57 = C57BL/6. 
1976; Fanselow, 1990). This phenomenon is called the immediate shock deficit, and Fanselow $(1986,1990)$ suggested that the deficit is caused by a failure of the animal to associate the contextual stimuli present at the time of the shock with the shock. Increasing the placement to shock interval with delays up to 2-min increases the amount of freezing to the context. In addition, allowing the rat to explore the conditioning chamber the day before the immediate shock increases the amount of freezing to the context. This increased exposure and resulting contextual fear is termed the CPFE. The pre-exposure establishes a representation of the context that can be retrieved by a brief exposure to the context prior to shock presentation. This effect has been reported primarily in rats (Kiernan and Westbrook, 1993; Rudy and O'Reilly, 1999; MatusAmat et al., 2004; Pham et al., 2005) but also in mice (Wiltgen et al., 2001; Frankland et al., 2004; McHugh and Tonegawa, 2007; Kenney and Gould, 2008; Goeldner et al., 2009).

Subsequent research has shown that the immediate shock deficit depends on the formation of a representation of the context and not on handling manipulations, novelty of the conditioning chamber (Landeira-Fernandez et al., 1995) or processing of the foot shock US (Landeira-Fernandez et al., 2006). An essential component of the context representation requires spatial exploration of the cues in the environment (McHugh and Tonegawa, 2007). Context-specific place cells in the CA1, CA3, and dentate gyrus subfields of the hippocampus provide spatial information to which the shock is associated. It has also been shown that rats condition to the pre-exposure environment and not the shock environment. If the pre-exposure context is different from the shock context, rats will show freezing when tested in the pre-exposure but not the shock context (Rudy and O'Reilly, 2001).

A potential explanation for the conflicting results of lesion and aging contextual fear conditioning studies is that conditioning can be supported by two distinct neural systems (Rudy et al., 2002, 2004; Rudy, 2009). The features of a context can be bound together into a conjunctive representation, and it is this unified, polymodal representation that becomes associated with the shock (Rudy and O'Reilly, 1999; O'Reilly and Rudy, 2001). A second system involves an elemental or feature representation of the context, whereby certain salient features become associated with the shock (Frankland et al., 1998). The conjunctive representation is supported by the hippocampus, whereas the elemental representation is supported by a neocortical system including the peri- and post-rhinal cortices (Rudy, 2009). The application of the CPFE paradigm has confirmed that the hippocampal system is indeed responsible for the conjunctive representation of the context and that elemental conditioning does not occur. Rats pre-exposed to the conditioning context but not those exposed to its individual features showed the CPFE (Rudy and O'Reilly, 1999). Neurotoxic lesions to the dorsal hippocampus before pre-exposure prevented the CPFE, and the same lesions did not affect standard context fear (Rudy et al., 2002). Additionally, pharmacologically inactivating either the neurons (Matus-Amat et al., 2004) or NMDA receptors (Matus-Amat et al., 2007) in the hippocampus prevented the CPFE but had no effect on standard context fear. Thus, in normal, intact rats, the role of the hippocampus is to create and store a conjunctive representation of the context as well as to inhibit elemental conditioning to individual features of the context. That standard context conditioning can occur in the absence of a functional hippocampus suggests that the secondary (neocortical) system is able to support the task through elemental associations (Rudy et al., 2002, 2004; Matus-Amat et al., 2004, 2007; Rudy, 2009).

The power of the CPFE paradigm is that it isolates the hippocampus-dependent portion of the fear conditioning task (conjunctive representation of the context) from the context-shock association. This paradigm guarantees a focus on the hippocampus, and number of studies have used this task to assess the specific contribution to cellular and molecular components of learning. Kenney and Gould (2008) reported that nicotine enhances context learning, but not the formation of the context-shock association. Other studies have implicated consolidation in the hippocampus as an essential component of the CPFE (Barrientos et al., 2002a,b; Frankland et al., 2004). Inhibiting protein synthesis in the dorsal hippocampus (thereby preventing consolidation of the conjunctive context representation) after pre-exposure led to a reduced CPFE (Barrientos et al., 2002a). A similar result was reported when the inflammatory cytokine IL- $1 \beta$ was injected after pre-exposure, though it also showed time-bound effects in that CPFE was not inhibited when the compound was injected $48 \mathrm{~h}$ after pre-exposure (Barrientos et al., 2002b).

Thus it seems that the hippocampus (1) rapidly acquires a conjunctive representation of the context upon pre-exposure, (2) stores this context representation, and (3) is needed for the activation of the context representation to be associated with the US shock (Matus-Amat et al., 2004; Matus-Amat et al., 2007; Rudy, 2009). In addition, the memory of the context can be activated by a subset of the original cues, which is referred to as pattern completion (Rudy and O'Reilly, 1999, 2001). Rudy et al. (2002) and Barrientos et al. (2002a,b) have developed a modification of the CPFE protocol that establishes an association between the contextual representation and the transport cues preceding the placement of the rat into the context. The method involves multiple exposures to the context in which the rat is transported in a distinct light-sealed black container. Thus, on shock and test days, the transport cues can activate the representation of the context. In this method the rat can be shocked immediately when placed in the chamber and still show robust context fear on test day, which eliminates the need for pattern completion to take place in the chamber on shock day as originally suggested by Fanselow (1990).

\section{Age deficits and age sensitivity}

To date, no study has incorporated the CPFE to examine changes in hippocampal function across the life span. There are a number of studies demonstrating that disruption of the hippocampus impairs the CPFE while sparing standard context fear (see Rudy et al., 2004; Rudy, 2009 for a review). It seems plausible that changes in synaptic efficiency and plasticity, which are thought to support age-related changes in behavior on tests of learning and memory, could act as "disruptions" comparable to the pharmacological and electrolytic lesions commonly used in the CPFE literature. It remains to be seen if aging in the hippocampus causes deficits in CPFE, but the paradigm seems ideal for these studies as it isolates the hippocampus-dependent aspects of context fear and is not confounded by the possibility of other neural systems maintaining the behavior. Sensitivity to hippocampus insult is certainly greater in 
Table 6 | Context pre-exposure facilitation effect: age sensitivity.

\begin{tabular}{|c|c|c|c|c|c|c|c|c|}
\hline Study & $\begin{array}{l}\text { Species/ } \\
\text { strain }\end{array}$ & $\begin{array}{l}\text { Age } \\
\text { (months) }\end{array}$ & $\begin{array}{l}\text { Age } \\
\text { deficits }\end{array}$ & $\begin{array}{l}\text { Mirror lesions } \\
\text { in young }\end{array}$ & $\begin{array}{l}\text { Confounds/strain } \\
\text { differences }\end{array}$ & $\begin{array}{l}\text { Effect of cognition- } \\
\text { enhancing drugs }\end{array}$ & $\begin{array}{l}\text { Cerebellum- } \\
\text { sensitive }\end{array}$ & $\begin{array}{l}\text { Hippocampus- } \\
\text { sensitive }\end{array}$ \\
\hline $\begin{array}{l}\text { Frankland } \\
\text { et al. (1998) }\end{array}$ & C57BL/6 & $3-5$ & & Lesions impair & & & & Yes \\
\hline $\begin{array}{l}\text { Kenney and } \\
\text { Gould (2008) }\end{array}$ & C57BL/6 & $2-3$ & & & & $\begin{array}{l}\text { Nicotine enhances } \\
\text { context learning }\end{array}$ & & Yes \\
\hline $\begin{array}{l}\text { Rudy et al. } \\
\text { (2002) }\end{array}$ & $\begin{array}{l}\text { Long- } \\
\text { Evans rat }\end{array}$ & & & Lesions impair & & & & Yes \\
\hline
\end{tabular}

Species is mouse unless otherwise specified. $C 57=$ C57BL/6.

the CPFE compared to standard contextual fear conditioning and theoretically this difference should make the CPFE more sensitive to processes of aging.

Based on the current CPFE literature, this test only satisfies the seventh Criterion - it seems to be a purely hippocampal task (see Table 6). Whereas standard contextual fear conditioning can be supported by a non-hippocampal neural system, the CPFE has no alternative neural substrates. Criterion 4 is also partially supported, in that young animals with lesions to the hippocampus show CPFE deficits expected in older animals. No study has investigated the CPFE in aged animals, so this criterion requires further exploration. No data exist to address the remaining five criteria and future studies are needed to determine the age sensitivity of the CPFE.

\section{CONCLUSION}

The ideal age-sensitive behavioral test in mice should:

1. Reliably discriminate between young and old animals on the target behavior

2. Avoid confounds from other processes (i.e., visuomotor in MWM, non-hippocampal system in context fear)

3. Avoid food restriction or other stressors that could weaken older animals

4. Mirror deficits of young lesioned animals in an aged population

5. Identify the differences in strain and show parallels across species

6. Reveal improved performance when animals are treated with drugs known to enhance behavior in the aged in clinical trials

7. Engage neural substrates that support learning and memory (hippocampus and/or cerebellum)

The behavioral tests discussed in this review have been implemented with varying amounts of success to assess normal aging in mice. To increase age sensitivity in cases where known strain differences exist (rotorod), multiple strains of rodent should be tested at multiple ages to account for different baseline performance combined with differential trajectories of ability across the life span. Differences become especially important when strains that provide a genetic background to models of degenerative disease and accelerated aging are involved. To account for heterogeneity of aging, particular attention should be paid to recognizing subpopulations of good and poor performing animals (MWM, EBCC). In addition, genetically heterogeneous mice created by a four-way cross (Sumien et al., 2006) are an attractive possibility that would lead to wider generalizability of age-related declines in cognitive performance across the life span compared to genetically uniform inbred strains most often utilized in rodent models of aging.

To improve age sensitivity in the MWM, manipulations to increase the task demand (repeated acquisition, working-memory versions) should be implemented. Dependent measures that are separate from motor skill biases such as platform crossings and distance traveled should be considered, while an emphasis solely on latency to escape should be avoided. If mice and rats perform differently on a particular task (Barnes maze), specific dependent measures should be included (primary path length, primary latency) to account for these differences. In the case of contextual fear conditioning, which does not appear to be age sensitive, methodologies that do not allow for alternate neural systems to support the behavior (such as the CPFE) should be applied to assess the contribution of the hippocampus to this task across the life span. Comparisons between multiple behavioral tests that differentially engage the structures of interest (i.e., fear conditioning, MWM and Barnes maze for the hippocampus) and those that have very well elaborated neural substrates and wide applicability to a number of species (EBCC) would yield the strongest conclusions.

In particular, two of the behavioral tests discussed here have been implemented in little (Barnes maze) to no (CPFE) studies of aging in the mouse, despite the fact that both show exceptional promise. A robust data set for the Barnes maze has been compiled in the rat, but no studies have evaluated the CPFE across the multiple ages in rodents. The data do not yet exist to draw satisfactory conclusions on the age sensitivity of these two tasks with respect to aging in mice. Studies assessing the performance of multiple strains (or heterogeneous mice) across the life span are needed.

\section{ACKNOWLEDGMENTS}

The authors would like to thank Dr. Thomas Gould and Dr. Vinay Parikh for their contributions to revisions of this manuscript. Portions of this research were supported by grants from the National Institute on Aging, 1 R01 AG021925 and 1 R01 AG023742 to Diana S. Woodruff-Pak. 


\section{REFERENCES}

Aguilar-Valles, A., Sanchez, E., de Gortari, P., Balderas, I., Ramirez-Amaya, V., Bermudez-Rattoni, F., and JosephBravo, P. (2005). Analysis of the stress response in rats trained in the water-maze: differential expression of corticotropin-releasing hormone, CRH-R1, glucocorticoid receptors and brain-derived neurotrophic factor in limbic regions. Neuroendocrinology $82,306-319$

Alvarez, R. P., Biggs, A., Chen, G., Pine, D. S., and Grillon, C. (2008). Contextual fear conditioning in humans: corticalhippocampal and amygdala contributions. J. Neurosci. 28, 6211-6219.

Ambrée, O., Richter, H., Sachser, N., Lewejohann, L., Dere, E., de Souza Silva, M. A., Herring, A., Keyvani, K., Paulus, W., and Schäbitz, W. R. (2009). Levodopa ameliorates learning and memory deficits in a murine model of Alzheimer's disease. Neurobiol. Aging 30, 1192-1204.

Anagnostaras, S. G., Gale, G. D., and Fanselow, M.S. (2001). Hippocampus and contextual fear conditioning: recent controversies and advances. Hippocampus 11, 8-17.

Anderson, B., Gunderson, H., and Pakkenberg, B. (2003). Aging of the human cerebellum: a stereological study. J. Comp. Neurol. 466, 356-365.

Arendash, G. W., and King, D. L. (2002). Intra- and intertask relationships in a behavioral test battery given to Tg2576 transgenic mice and controls. Physiol. Behav. 75, 643-652

Bach, M. E., Barad, M., Son, H., Zhuo, M., Lu, Y. F., Shih, R., Mansuy, I., Hawkins, R. D., and Kandel, E. R. (1999). Age-related defects in spatial memory are correlated with defects in the late phase of hippocampal long-term potentiation in vitro and are attenuated by drugs that enhance the cAMP signaling pathway. Proc. Natl. Acad. Sci. U.S.A. 96, 5280-5285.

Bannerman, D. M., Yee, B. K., Good, M. A., Heupel, M. J., Iversen, S. D., and Rawlins, J. N. P. (1999). Double dissociation of function within the hippocampus: a comparison of dorsal, ventral, and complete hippocampal cytotoxic lesions. Behav. Neurosci. 113, 1170-1188.

Barnes, C. A. (1979). Memory deficits associated with senescence - neurophysiological and behavioral - study in the rat. J. Comp. Physiol. Psychol. 93, 74-104.

Barnes, C.A.(1999). Do synaptic markers provide a window on synaptic effectiveness in the aged hippocampus? Neurobiol. Aging 20, 349-351.
Barnes, C. A., Forster, M. J., Fleshner, M., Ahanotu, E. N., Laudenslager, M. L., Mazzeo, R. S., Maier, S. F., and Lal, H. (1991). Exercise does not modify spatial memory, brain autoimmunity, or antibody-response in aged F344 rats. Neurobiol. Aging. 12, 47-53.

Barnes, C. A., Nadel, L., and Honig, W. K. (1980).Spatial memory deficit in senescent rats. Can. J. Psychol. 34, 29-39.

Barrett, G. L., Bennie, A., Trieu, J., Ping, S., and Tsafoulis, C. (2009). The chronology of age-related spatial learning impairment in two rat strains, as tested by the Barnes maze. Behav. Neurosci. 123, 533-538.

Barrientos, R. M., Higgins, E. A., Sprunger, D. B., Watkins, L. R., Rudy, J. W., and Maier, S. F. (2002a). Memory for context is impaired by a post context exposure injection of interleukin-1 beta into dorsal hippocampus. Behav. Brain Res. 134 291-298.

Barrientos, R. M., O'Reilly, R. C., and Rudy, J. W. (2002b). Memory for context is impaired by injecting anisomycin into dorsal hippocampus following context exploration. Behav. Brain Res 34, 299-306.

Bartus, R. T., Flicker, C., and Dean, R. L. (1983). "Logical principles for the development of animal models of age-related memory impairment," in Assessment in Geriatric Psychopharmacology, eds T. Crook, S. Ferris, and R. T. Bartus (Madison, CT: Powley Associates), 263-300.

Bearzatto, B., Servais, L., Cheron, G., and Schiffmann, S. N. (2005). Age dependence of strain determinant on mice motor coordination. Brain Res. 1039, 37-42.

Bellush, L. L., Wright, A. M., Walker, J. P., Kopchick, J., and Colvin, R. A. (1996) Caloric restriction and spatial learning in old mice. Physiol. Behav. 60, 541-547.

Berger, T.W., Alger, B., and Thompson, R. F. (1976). Neuronal substrate of classical conditioning in hippocampus. Science 192, 483-485.

Berger, T. W., Rinaldi, P. C., Weisz, D. J., and Thompson, R. F. (1983). Single-unit analysis of different hippocampal cell types during classical conditioning of rabbit nictitatingmembrane response. J. Neurophysiol. $50,1197-1219$.

Berteau-Pavy, F., Park, B., and Raber, J. (2007). Effects of sex and APOE epsilon 4 on object recognition and spatial navigation in the elderly. Neuroscience 147, 6-17.

Bickford, P. (1995). Aging and motor learning - a possible role for norepinephrine in cerebellar plasticity. Rev. Neurosci. 6, 35-46.
Biggers, J.D., Finn, C. A., and McLaren, A (1962). Long-term reproductive performance of female mice. I. Effect of removing one ovary. J. Reprod. Fertil. 3, 303-312.

Blanchard, R. J., Fukunaga, K. K., and Blanchard, D. C. (1976). Environmental control of defensive reactions to footshock. Bull. Psychon. Soc. 8, 129-130

Bondolfi, L., Ermini, F., Long, J. M., Ingram, D. K., and Jucker, M. (2004) Impact of age and caloric restriction on neurogenesis in the dentate gyrus of C57BL/6 mice. Neurobiol. Aging 25 333-340.

Brown, K. L., Agelan, A., and WoodruffPak, D. S. (2010). Unimpaired trace eyeblink classical conditioning in Purkinje cell degeneration (pcd) mutant mice. Neurobiol. Learn. Mem. 93, 303-311.

Burwell, R. D., Saddoris, M. P., Bucci, D. J., and Wiig, K. A. (2004) Corticohippocampal contributions to spatial and contextual learning. $J$. Neurosci. 24, 3826-3836.

Cattell, R. B. (1941). Some theoretical issues in adult intelligence testing. Psychol. Bull. 38, 592.

Cattell, R. B. (1943). The measurement of adult intelligence. Psychol. Bull. 40, 153-193.

Chen, L., Bao, S. W., Lockard, J. M., Kim, J. J., and Thompson, R. F. (1996). Impaired classical eyeblink conditioning in cerebellar-lesioned and Purkinje cell degeneration (pcd) mutant mice. J. Neurosci. 16, 2829-2838.

Chen, L., Bao, S. W., and Thompson, R. F. (1999). Bilateral lesions of the interpositus nucleus completely prevent eyeblink conditioning in Purkinje cell degeneration mutant mice. Behav. Neurosci. 113, 204-210.

Christian, K. M., and Thompson, R. F. (2003). Neural substrates of eyeblink conditioning: acquisition and retention. Learn. Mem. 10, 427-455.

Colombel, C., Lalonde, R., and Caston, J. (2004). The effects of unilatera removal of the cerebellar hemispheres on spatial learning and memory in rats. Brain Res. 1004 , 108-115.

Conrad, H. S., Jones, H. E., and Hsiao, H. H. (1933). Sex differences in mental growth and decline. J. Educ. Psychol. 24, 161-169.

Contet, C., Rawlins, J.N. P., and Deacon, R M. J. (2001). A comparison of 12952 SvHsd and C57BL/6JOlaHsd mice on a test battery assessing sensorimotor affective and cognitive behaviours: implications for the study of genetically modified mice. Behav. Brain Res. 124, 33-46.
Crawley, J. N., Belknap, J. K., Collins, A. Crabbe, J. C., Frankel, W., Henderson, N., Hitzemann, R. J., Maxson, S. C., Miner, L. L., Silva, A. J., Wehner, J. M., Wynshaw-Boris, A., and Paylor, R. (1997). Behavioral phenotypes of inbred mouse strains: implications and recommendations for molecular studies. Psychopharmacology 132, 107-124.

Cuppini, R., Bucherelli, C., Arnbrogini, P., Ciuffoli, S., Orsini, L., Ferri, P., and Baldi, E. (2006). Age-related naturally occurring depression of hippocampal neurogenesis does not affect trace fear conditioning. Hippocampus 16, 141-148.

Dahhaoui, M., Stelz, T., and Caston, J. (1992). Effects of lesion of the inferior olivary complex by 3 -acetylpyridine on learning and memory in the rat. $J$. Comp. Physiol. A 171, 657-664.

de Fiebre, N. C., Sumien, N., Forster, M. J., and de Fiebre, C. M. (2006) Spatial learning and psychomotor performance of C57BL/6 mice: age sensitivity and reliability of individual differences. Age 28, 235-253.

Doyere, V., Gisquet-Verrier, P., de Marsanich, B., and Ammassari-Teule, M. (2000). Age-related modifications of contextual information processing in rats: role of emotional reactivity, arousal and testing procedure. Behav. Brain Res. 114, 153-165.

Fabricius, K., Wortwein, G., and Pakkenberg, B. (2008). The impact of maternal separation on adult mouse behaviour and on the total neuron number in the mouse hippocampus. Brain Struct. Funct. 212, 403-416.

Fanselow, M. S. (1986). Associative vs. topographical accounts of the immediate shock freezing deficit in rats: implications for the response selection-rules governing speciesspecific defensive reactions. Learn. Motiv. 17, 16-39.

Fanselow, M. S. (1990). Factors governing the one-trial contextual conditioning. Anim. Learn. Behav. 18, 264-270.

Feiro, O., and Gould, T. J. (2005). The interactive effects of nicotinic and muscarinic cholinergic receptor inhibition on fear conditioning in young and aged C57BL/6 mice. Pharmacol. Biochem. Behav. 80, 251-262.

Fetsko, L. A., Xu, R., and Wang, Y. Y. (2005). Effects of age and dopamine D2L receptor-deficiency on motor and learning functions. Neurobiol. Aging 26, 521-530.

Fontana, D. J., Daniels, S. E., Henderson, C., Eglen, R. M., and Wong, E. H. F (1995). Ondansetron improves cognitive performance in the Morris water maze spatial navigation task. Psychopharmacology 120, 409-417. 
Fox, R. R. (1980). The rabbit (oryctolaguscuniculus) and research on aging. Exp. Aging Res. 6, 235-248.

Francia, N., Cirulli, F., Chiarotti, F., Antonelli, A., Aloe, L., and Alleva, E. (2006). Spatial memory deficits in middle-aged mice correlate with lower exploratory activity and a subordinate status: role of hippocampal neurotrophins. Eur. J. Neurosci. 23, 711-728.

Frankland, P. W., Cestari, V., Filipkowski, R. K., McDonald, R. J., and Silva, A. J. (1998). The dorsal hippocampus is essential for context discrimination but not for contextual conditioning. Behav. Neurosci. 112, 863-874.

Frankland, P. W., Josselyn, A., Anagnostaras, S. G., Kogan, J. H., Takahashi, E., and Silva, A. J. (2004). Consolidation of CS and US representations in associative fear conditioning. Hippocampus 14, 557-569.

Frick, K. M., Baxter, M. G., Markowska, A. L., Olton, D. S., and Price, D. L. (1995). Age-related spatial reference and working-memory deficits assessed in the water maze. Neurobiol. Aging 16, $149-160$

Gage, F. H., Dunnett, S. B., and Bjorklund, A. (1984). Spatial learning and motor deficits in aged rats. Neurobiol. Aging 5, 43-48.

Gage, F. H., Dunnett, S. B., and Bjorklund, A. (1989). Age-related impairments in spatial memory are independent of those in sensorimotor skills. Neurobiol. Aging 10, 347-352.

Gale, G. D., Anagnostaras, S. G., and Fanselow, M. S. (2001). Cholinergic modulation of pavlovian fear conditioning: effects of intrahippocampal scopolamine infusion. Hippocampus $11,371-376$.

Gallagher, M., and Burwell, R. D. (1989). Relationship of age-related decline across several behavioral domains. Neurobiol. Aging 10, 691-708.

Gallagher, M., Burwell, R. D., and Burchinal, M. (1993). Severity of spatial-learning impairment in aging: development of a learning index for performance in the Morris water maze. Behav. Neurosci. 107, 618-626.

Gallagher, M., and Nicolle, M. M. (1993). Animal models of normal aging: relationships between cognitive decline and markers in hippocampal circuitry. Behav. Brain Res. 57, 155-162.

Gasbarri, A., Pompili, A., Pacitti, C., and Cicirata, F. (2003). Comparative effects of lesions to the ponto-cerebellar and olivo-cerebellar pathways on motor and spatial learning in the rat. Neuroscience 116, 1131-1140.

Geinisman, Y., deToledo-Morrell, L., Morrell, F., Persina, I. S., and Rossi, M. (1992). Age-related loss of axospinous synapses formed by 2 afferent systems in the rat dentate gyrus revealed by the unbiased stereological dissector technique. Hippocampus 2, 437-444.

Gerlai, R. (1998). Contextual learning and cue association in fear conditioning in mice: a strain comparison and a lesion study. Behav. Brain Res. 95, 191-203.

Gerlai, R., and Roder, J. (1996). Spatial and nonspatial learning in mice: effects of S100 beta overexpression and age. Neurobiol. Learn. Mem. 66, 143-154.

Goeldner, C., Reiss, D., Wichmann, J., Kieffer, B. L., and Ouagazzal, A. M. (2009). Activation of nociceptin opioid peptide (NOP) receptor impairs contextual fear learning in mice through glutamatergic mechanisms. Neurobiol. Learn. Mem. 91, 393-401.

Goodlett, C. R., Hamre, K. M., and West, J. R. (1992). Dissociation of spatial navigation and visual guidance performance in Purkinje cell degeneration (pcd) mutant mice. Behav. Brain Res. 47, 129-141.

Gould, T. J., and Feiro, O. R. (2005). Agerelated deficits in the retention of memories for cued fear conditioning are reversed by galantamine treatment. Behav. Brain Res. 165, 160-171.

Gould, T. J., Rowe, W. B., Heman, K. L. Mesches, M. H., Young, D. A., Rose, G. M., and Bickford, P. C. (2002). Effects of hippocampal lesions on patterned motor learning in the rat. Brain Res. Bull. 58, 581-586.

Gould, T. J., and Wehner, J. M. (1999). Nicotine enhancement of contextual fear conditioning. Behav. Brain Res. 102, 31-39.

Gower, A. J., and Lamberty, Y. (1993). The aged mouse as a model of cognitive decline with special emphasis on studies in NMRI mice. Behav. Brain Res. $57,163-173$.

Green, J. T., and Woodruff-Pak, D. S (2000). Eyeblink classical conditioning: hippocampal formation is for neutral stimulus associations as cerebellum is for association-response. Psychol. Bull. 126, 138-158.

Greenough, W. T., McDonald, J. W., Parnisari, R. M., and Camel, J. E. (1986). Environmental conditions modulate degeneration and new dendrite growth in cerebellum of senescent rats. Brain Res. 380, 136-143.

Grootendorst, J., de Kloet, E. R., Vossen, C., Dalm, S., and Oitzl, M. S. (2001). Repeated exposure to rats has persistent genotype-dependent effects on learning and locomotor activity of apolipoprotein Eknockout and C57B1/6 mice. Behav. Brain Res. 125, 249-259.

Haley, G. E., and Raber, J. (2011). "Spatial learning and memory in animal models and humans," in Animal Models of Behavioral Analysis, ed J. Raber (New York: Humana Press), 91-109.
Harburger, L. L., Lambert, T. J., and Frick, K. M. (2007). Age-dependent effects of environmental enrichment on spatial reference memory in male mice. Behav. Brain Res. 185, 43-48.

Harrison, F. E., Reiserer, R. S., Tomarken, A. J., and McDonald, M. P. (2006) Spatial and nonspatial escape strategies in the Barnes maze. Learn. Mem $13,809-819$.

Harrison, F.E., Hosseini, A. H., McDonald, M. P., and May, J. M. (2009a).Vitamin $\mathrm{C}$ reduces spatial learning deficits in middle-aged and very old APP/ PSEN1 transgenic and wild-type mice. Pharmacol. Biochem. Behav. 93 443-450.

Harrison, F. E., Hosseini, A. H., and McDonald, M.P.(2009b).Endogenous anxiety and stress responses in water maze and Barnes maze spatial memory tasks. Behav. Brain Res. 198, 247-251.

Harrison, J., and Buchwald, J. (1983) Eyeblink conditioning deficits in the old cat. Neurobiol. Aging 4, 45-51.

Heine, V. M., Maslam, S., Joels, M., and Lucassen, P. J. (2004). Prominent decline of newborn cell proliferation, differentiation, and apoptosis in the aging dentate gyrus, in absence of an age-related hypothalamus-pituitaryadrenal axis activation. Neurobiol. Aging 25, 361-375.

Hilber, P., Jouen, F., Delhaye-Bouchaud N., Mariani, J., and Caston, J. (1998). Differential roles of cerebellar cortex and deep cerebellar nuclei in learning and retention of a spatial task: studies in intact and cerebellectomized Lurcher mutant mice Behav Genet 28, 299-308.

Horn, J. L. (1968). Organization of abilities and development of intelligence. Psychol. Rev. 75 .

Horn, J. L. (1975). Geriatric psychopharmacology: the scene today. Psychopharmacol. Bull. 11, 44-45.

Horn, J. L., and Cattell, R. B. (1966). Refinement and test of a theory of fluid and crystallized intelligences. $J$. Educ. Psychol. 57.

Horn, J. L., and Cattell, R. B. (1967). Age differences in fluid and crystallized intelligence. Acta Psychol. 26.

Houston, F. P., Stevenson, G. D. McNaughton, B. L., and Barnes, C. A (1999). Effects of age on the generalization and incubation of memory in the F344 rat. Learn. Mem. 6, 111-119.

Huerta, P. T., Sun, L. D., Wilson, M. A. and Tonegawa, S. (2000). Formation of temporal memory requires NMDA receptors within CA1 pyramidal neurons. Neuron 25, 473-480.

Ingram, D. K. (1983). Toward the behavioral assessment of biological aging in the laboratory mouse: concepts, terminology and objectives. Exp. Aging Res. 9, 225-238.
Ingram, D. K., and Jucker, M. (1999). Developing mouse models of aging: a consideration of strain differences in age-related behavioral and neural parameters. Neurobiol. Aging 20, 137-145.

Ingram, D. K., Weindruch, R., Spangler, E. L., Freeman, J. R., and Walford, R. L. (1987). Dietary restriction benefits learning and motor performance of aged mice. J. Gerontol. 42, 78-81.

Ito, M. (1989). Long-term depression. Annu. Rev. Neurosci. 12, 85-102.

Jones, H. E., and Conrad, H. S. (1933). The growth and decline of intelligence: a study of a homogeneous group between the ages of ten and sixty. Genet. Psychol. Monogr. 13, 223-298.

Jucker, M., and Ingram, D. K. (1997). Murine models of brain aging and age-related neurodegenerative diseases. Behav. Brain Res. 85, 1-25.

Kaczorowski, C. C., and Disterhoft, J. F. (2009). Memory deficits are associated with impaired ability to modulate neuronal excitability in middle-aged mice. Learn. Mem. 16, 362-366.

Kaneko, T., and Thompson, R. F. (1997). Disruption of trace conditioning of the nictitating membrane response in rabbits by central cholinergic blockade. Psychopharmacology 131, 161-166.

Kempermann, G., Kuhn, H. G., and Gage, F. H. (1997). More hippocampal neurons in adult mice living in an enriched environment. Nature 386, 493-495.

Kenney, J. W., and Gould, T. J. (2008) Nicotine enhances context learning but not context-shock associative learning. Behav. Neurosci. 122, 1158-1165.

Kiernan, M. J., and Westbrook, R. F. (1993). Effects of exposure to a tobe-shocked environment upon the rat's freezing response: evidence for facilitation, latent inhibition, and perceptual learning. Q. J. Exp. Psychol. B 46, 271-288.

Kim, J. J., Clark, R. E., and Thompson, R. F. (1995). Hippocampectomy impairs the memory of recently, but not remotely, acquired trace eveblink conditioned responses. Behav. Neurosci. 109, 195-203.

Kim, J. J., and Fanselow, M. S. (1992). Modality-specific retrograde amnesia of fear. Science 256, 675-677.

King, D. L., and Arendash, G. W. (2002). Behavioral characterization of the Tg2576 transgenic model of Alzheimer's disease through 19 months. Physiol. Behav. 75, 627-642.

Kishimoto, Y., Hirono, M., Sugiyama, T., Kawahara, S., Nakao, K., Kishio, M., Katsuki, M., Yoshioka, T., and Kirino, Y. (2001a).Impaired delay but normal 
trace eyeblink conditioning in PLC beta 4 mutant mice. Neuroreport 12 , 2919-2922.

Kishimoto, Y., Kawahara, S., Fujimichi, R., Mori, H., Mishina, M., and Kirino, Y. (2001b). Impairment of eyeblink conditioning in GluR delta 2-mutant mice depends on the temporal overlap between conditioned and unconditioned stimuli. Eur. J. Neurosci. 14, 1515-1521.

Kishimoto, Y., Suzuki, M., Kawahara, S., and Kirino, Y. (2001c). Agedependent impairment of delay and trace eyeblink conditioning in mice. Neuroreport 12, 3349-3352.

Kishimoto, Y., Fujimichi, R., Araishi, K. Kawahara, S., Kano, M., Aiba, A., and Kirino, Y. (2002). mGluR1 in cerebellar Purkinje cells is required for normal association of temporally contiguous stimuli in classical conditioning. Eur. J. Neurosci. 16, 2416-2424.

Klapdor, K., and van der Staay, F. J. (1996). The Morris water-escape task in mice: strain differences and effects of intramaze contrast and brightness. Physiol. Behav. 60, 1247-1254.

Koopmans, G., Blokland, A., van Nieuwenhuijzen, P., and Prickaerts, J. (2003). Assessment of spatial learning abilities of mice in a new circular maze. Physiol. Behav. 79, 683-693.

Kronforst-Collins, M. A., and Disterhoft, J. F. (1998). Lesions of the caudal area of rabbit medial prefrontal cortex impair trace eyeblink conditioning. Neurobiol. Learn. Mem. 69, 147-162.

Lalonde, R., Bensoula, A. N., and Filali, M. (1995). Rotorod sensorimotor learning in cerebellar mutant mice. Neurosci. Res. 22, 423-426.

Lalonde, R., and Strazielle, C. (2003a). The effects of cerebellar damage on maze learning in animals. Cerebellum 2, 300-309.

Lalonde, R., and Strazielle, C. (2003b). Motor coordination, exploration, and spatial learning in a natural mouse mutation (nervous) with Purkinje cell degeneration. Behav. Genet.33,59-66.

Landeira-Fernandez, J., Fanselow, M. S., DeCola, J. P., and Kim, J. J. (1995). Effects of handling an context preexposure on the immediate shock deficit. Anim. Learn. Behav. 23, 335-339.

Landeira-Fernandez,J., Kim, J. J., DeCola, J. P., and Fanselow, M. S. (2006). Immediate shock deficit in fear conditioning: effects of shock manipulations. Behav. Neurosci. 120, 873-879.

Larsen, J., Skalicky, M., and Viidick, A. (2000). Does long-term physical exercise counteract age-related Purkinje cell loss? A stereological study of rat cerebellum. J Comp Neurol. 428, 213-222.

Le Marec, N., and Lalonde, R. (1997). Sensorimotor learning and retention during equilibrium tests in Purkinje cell degeneration mutant mice. Brain Res. 768, 310-316.

Le Marec, N., Stelz, T., Delhaye-Bouchaud, N., Mariani, J., and Caston, J. (1997). Effect of cerebellar granule cell depletion on learning of the equilibrium behaviour: study in postnatally X-irradiated rats. Eur. J. Neurosci. 9 , 2472-2478.

Lee, J. M., Ross, E. R., Gower, A., Paris, J. M., Martensson, R., and Lorens, S. A. (1994). Spatial learning deficits in the aged rat: neuroanatomical and neurochemical correlates. Brain Res. Bull. 33, 489-500.

Linden, D. J., and Connor, J. A., (1995). Long-term synaptic depression. Annu. Rev. Neurosci. 18, 319-357.

Lindner, M. D., and Schallert, T. (1988). Aging and atropine effects on spatial navigation in the Morris water task. Behav. Neurosci. 102, 621-634.

Liu, R. L., Liu, I. Y., Bi, X. N., Thompson, R. F., Doctrow, S. R., Malfroy, B., and Baudry, M. (2003). Reversal of agerelated learning deficits and brain oxidative stress in mice with superoxide dismutase/catalase mimetics. Proc. Natl. Acad. Sci. U.S.A. 100, 8526-8531.

Logue, S. E., Paylor, R., and Wehner, J. M. (1997a). Hippocampal lesions cause learning deficits in inbred mice in the Morris water maze and conditionedfear task. Behav. Neurosci.111, 104-113.

Logue, S. F., Owen, E. H., Rasmussen, D. L. and Wehner,J.M. (1997b). Assessment of locomotor activity, acoustic and tactile startle, and prepulse inhibition of startle in inbred mouse strains and F-1 hybrids: implications of genetic background for single gene and quantitative trait loci analyses. Neuroscience 80 , 1075-1086.

Magnusson, K. R., Scruggs, B., Aniya, J., Wright, K. C., Ontl, T., Xing, Y. D., and Bai, L. (2003). Age-related deficits in mice performing working memory tasks in a water maze. Behav. Neurosci. 117, 485-495.

Maren, S. (1999). Neurotoxic or electrolytic lesions of the ventral subiculum produce deficits in the acquisition and expression of pavlovian fear conditioning in rats. Behav. Neurosci. 113, 283-290.

Maren, S., Aharonov, G., and Fanselow, M.S. (1997). Neurotoxic lesions of the dorsal hippocampus and Pavlovian fear conditioning in rats. Behav. Brain Res. 88, 261-274.

Maren, S., Anagnostaras, S. G., and Fanselow, M. S. (1998). The startled seahorse: is the hippocampus necessary for contextual fear conditioning? Trends Cogn. Sci. 2, 39-42.

Markowska, A. L., Spangler, E. L., and Ingram, D. K. (1998). Behavioral assessment of the senescence-accelerated mouse (SAM P8 and R1). Physiol. Behav. 64, 15-26.

Martin, L. A., Goldowitz, D., and Mittleman, G. (2003). The cerebellum and spatial ability: dissection of motor and cognitive components with a mouse model system. Eur. J. Neurosci. 18, 2002-2010.

Matus-Amat, P., Higgins, E. A., Barrientos, R. M., and Rudy, J. W. (2004). The role of the dorsal hippocampus in the acquisition and retrieval of context memory representations. J. Neurosci. 24, 2431-2439.

Matus-Amat, P., Higgins, E. A., Sprunger, D., Wright-Hardesty, K., and Rudy, J. W. (2007). The role of dorsal hippocampus and basolateral amygdala NMDA receptors in the acquisition and retrieval of context and contextual fear memories. Behav. Neurosci. 121, 721-731.

McEchron, M. D., Bouwmeester, H. Tseng, W., Weiss, C., and Disterhoft, J. F. (1998).Hippocampectomy disrupts auditory trace fear conditioning and contextual fear conditioning in the rat. Hippocampus 8, 638-646.

McEwen, B. S., and Magarinos, A. M. (2001). Stress and hippocampal plasticity: implications for the pathophysiology of affective disorders. Hum. Psychopharmacol. 16, S7-S19.

McEwen, B. S., Weiss, J. M., and Schwartz, L. S. (1968). Selective retention of corticosterone by limbic structures in the rat brain. Nature 220, 911.

McHugh, T. J., and Tonegawa, S. (2007) Spatial exploration is required for the formation of contextual fear memory. Behav. Neurosci. 121, 335-339.

McLay, R. N., Freeman, S. M., Harlan, R. E., Kastin, A. J., and Zadina, J. E. (1999) Tests used to assess the cognitive abilities of aged rats: their relation to each other and to hippocampal morphology and neurotrophin expression. Gerontology 45, 143-155.

McLay, R. N., Freeman, S. M., and Zadina, J. E. (1998). Chronic corticosterone impairs memory performance in the Barnes maze. Physiol. Behav. 63, 933-937.

McNaughton, B. L., Barnes, C. A., Rao, G., Baldwin, J., and Rasmussen, M. (1986). Long-term enhancement of hippocampal synaptic transmission and the acquisition of spatial information. J. Neurosci. 6, 563-571.

Mela, F., Millan, M. J., Brocco, M., and Morari, M. (2010). The selective $\mathrm{D}_{3}$ receptor antagonist, S33084, improves parkinsonian-like motor dysfunction but does not affect L-DOPA-induced dyskinesia in 6-hydroxydopamine hemi-lesioned rats. Neuropharmacology 58, 528-536.
Mesches, M. H., Gemma, C., Veng, L. M., Allgeier, C., Young, D. A., Browning, M. D., and Bickford, P. C. (2004). Sulindac improves memory and increases NMDA receptor subunits in aged Fischer 344 rats. Neurobiol. Aging 25, 315-324.

Milani, H., Uemura, U. U., Oliveira, R. M. W., Lepri, E. R., and Xavier, G. F. (1998). Loss of CAl cells following global ischaemia correlates with spatial deficits in the circular platform task. J. Neurosci. Methods 80, 19-27.

Miranda, R., Blanco, E., Begega, A., Rubio, S., and Arias, J. L. (2006). Hippocampal and caudate metabolic activity associated with different navigational strategies. Behav. Neurosci. 120, 641-650.

Miyagawa, H., Hasegawa, M., Fukuta, T., Amano,M., Yamada, K., and Nabeshima, T. (1998). Dissociation of impairment between spatial memory, and motor function and emotional behavior in aged rats. Behav. Brain Res. 91, 73-81.

Moffat, S. D., and Resnick, S. M. (2002). Effects of age on virtual environment place navigation and allocentric cognitive mapping. Behav. Neurosci. 116, 851-859.

Mons, N., Segu, L., Nogues, X., and Buhot, M. C. (2004). Effects of age and spatial learning on adenylyl cyclase mRNA expression in the mouse hippocampus. Neurobiol. Aging 25, 1095-1106.

Moreau, P. H., Cosquer, B., Jeltsch, H., Cassel, J. C., and Mathis, C. (2008). Neuroanatomical and behavioral effects of a novel version of the cholinergic immunotoxin mu p75-saporin in mice. Hippocampus 18, 610-622.

Morris, R. G. M., Garrud, P., Rawlins, J. N. P., and Okeefe, J. (1982). Place navigation impaired in rats with hippocampal lesions Nature 297, 681-683.

Nguyen, P. V., Abel, T., Kandel, E. R., and Bourtchouladze, R. (2000). Straindependent differences in LTP and hippocampus-dependent memory in inbred mice. Learn. Mem. 7, 170-179.

Nicolle, M. M., Gallagher, M., and McKinney, M. (1999a). Analyses of hippocampal circuitry in aging. Neurobiol. Aging 20, 359-360.

Nicolle, M. M., Gallagher, M., and McKinney, M. (1999b). No loss of synaptic proteins in the hippocampus of aged, behaviorally impaired rats. Neurobiol. Aging 20, 343-348.

Nyffeler, M., Yee, B. K., Feldon, J., Knuesel, I. (2010). Abnormal differentiation of newborn granule cells in age-related working memory impairments. Neurobiol. Aging 31, 1956-1974.

Ohlemiller, K. K. (2009). Mechanisms and genes in human strial presbycusis from animal models. Brain Res. 1277, 70-83.

Oler, J. A., and Markus, E. J. (1998). Agerelated deficits on the radial maze 
and in fear conditioning: hippocampal processing and consolidation. Hippocampus 8, 402-415.

O'Reilly, R. C., and Rudy, J. W. (2001). Conjunctive representations in learning and memory: principles of cortical and hippocampal function. Psychol. Rev. 108, 311-345.

Ouagazzal, A. M., Reiss, D., and Romand, R. (2006). Effects of age-related hearing loss on startle reflex and prepulse inhibition in mice on pure and mixed C57BL and 129 genetic background. Behav. Brain Res. 172, 307-315.

Owen, E. H., Logue, S. F., Rasmussen, D. L., and Wehner, J. M. (1997). Assessment of learning by the Morris water task and fear conditioning in inbred mouse strains and F-1 hybrids: implications of genetic background for single gene mutations and quantitative trait loci analyses. Neuroscience 80, 1087-1099.

Patil, S. S., Sunyer, B., Hoger, H., and Lubec, G. (2009). Evaluation of spatial memory of C57BL/6J and CD1 mice in the Barnes maze, the Multiple $\mathrm{T}$-maze and in the Morris water maze. Behav. Brain Res. 198, 58-68.

Paylor, R., Tracy, R., Wehner, J., and Rudy, J. W. (1994). DBA/2 and C57BL/6 mice differ in contextual fear but not auditory fear conditioning. Behav. Neurosci. 108, 810-817.

Pham, K., McEwen, B. S., LeDoux, J. E., and Nader, K. (2005). Fear learning transiently impairs hippocampal cell proliferation. Neuroscience 130, 17-24.

Phillips, R. G., and LeDoux, J. E. (1992). Differential contribution of amygdala and hippocampus to cued and contextual fear conditioning. Behav. Neurosci. 106, 274-285.

Pompl, P. N., Mullan, M. J., Bjugstad, K., and Arendash, G. W. (1999). Adaptation of the circular platform spatial memory task for mice: use in detecting cognitive impairment in the APP(SW) transgenic mouse model for Alzheimer's disease. J. Neurosci. Methods 87, 87-95.

Popesco, M. C., Lin, S. L., Wang, Z. L., Ma, Z. X. J., Friedman, L., Frostholm, A., and Rotter,A. (2008). Serial analysis of gene expression profiles of adult and aged mouse cerebellum. Neurobiol. Aging 29, 774-788.

Poucet, B., Herrmann, T., and Buhot, M. C. (1991). Effects of short-lasting inactivations of the ventral hippocampus and medial septum on long-term and short-term acquisition of spatial information in rats. Behav. Brain Res. 44, 53-65.

Pouzet, B., Zhang, W. N., Feldon, J., and Rawlins, J. N. P. (2002). Hippocampal lesioned rats are able to learn a spatial position using non-spatial strategies. Behav. Brain Res. 133, 279-291.
Pritchett, K. R., and Taft, R. A. (2006). "Reproductive biology of the laboratory mouse," in The Mouse in Biomedical Research, Vol. 3: Normative Biology, Husbandry and Models, 2nd Edn., eds J. G. Fox, S. Barthold, M. Davisson, C. E. Newcomer, F. W. Quimby, and A. Smith (Burlington, MA: Academic Press), 92-114.

Prut, L., Abramowski, D., Krucker, T., Levy, C. L., Roberts, A. J., Staufenbiel, M., and Wiessner, C. (2007). Aged APP23 mice show a delay in switching to the use of a strategy in the Barnes maze. Behav. Brain Res. 179, 107-110.

Rasmussen, T., Schliemann, T., Sorensen, J.C.,Zimmer, J., and West, M. J. (1996). Memory impaired aged rats: no loss of principal hippocampal and subicular neurons. Neurobiol. Aging 17, 143-147.

Rodrigues, S. M., LeDoux, J. E., and Sapolsky, R. M. (2009). The influence of stress hormones on fear circuitry. Annu. Rev. Neurosci. 32, 289-313.

Rodriguez-Moreno, A., Carrion, M. and Delagado-Garcia, J. M. (2006). The nicotinic agonist RJR-2403 compensates the impairment of eyeblink conditioning produced by the noncompetitive NMDA-receptor antagonist MK-801. Neurosci. Lett. 402, 102-107.

Rudy, J.W. (1993). Contextual conditioning and auditory cue conditioning dissociate during development. Behav. Neurosci. 107, 887-891.

Rudy, J. W. (2009). Context representations, context functions, and the parahippocampal-hippocampal system. Learn Mem. 16, 573-585.

Rudy, J.W., Barrientos, R. M., and O'Reilly, R.C. (2002). Hippocampal formation supports conditioning to memory of a context. Behav. Neurosci. 116,530-538.

Rudy, J.W., Huff, N.C., and Matus-Amat, P. (2004). Understanding contextual fear conditioning: insights from a twoprocess model. Neurosci. Biobehav. Rev. 28, 675-685.

Rudy, J. W., and O'Reilly, R. C. (1999). Contextual fear conditioning, conjunctive representations, pattern completion, and the hippocampus. Behav. Neurosci. 113, 867-880.

Rudy, J. W., and O'Reilly, R. C. (2001). Conjunctive representations, the hippocampus, and contextual fear conditioning. Cogn. Affect. Behav. Neurosci. $1,66-82$.

Schaie, K. W. (1974). Translations in gerontology: from lab to life: intellectual functioning. Am. Psychol. 29, 802-807

Schmaltz, L. W., and Theios, J. (1972). Acquisition and extinction of a classically conditioned response in hippocampectomized rabbits (oryctolagus-cuniculus). J. Comp. Physiol. Psychol. 79.
Selden, N. R. W., Everitt, B. J., Jarrard, L. E., and Robbins, T. W. (1991) Complementary roles for the amygdala and hippocampus in aversiveconditioning to explicit and contextual cues. Neuroscience 42, 335-350.

Serradj, N., and Jamon, M. (2007). Agerelated changes in the motricity of the inbred mice strains 129/sv and C57BL/6j. Behav. Brain Res. 177, 80-89.

Shukitt-Hale, B., Mouzakis, G., and Joseph, J. A. (1998). Psychomotor and spatial memory performance in aging male Fischer 344 rats. Exp. Gerontol. 33, 615-624.

Smith, T. D., Calhoun, H. E., and Rapp P. R. (1999). Circuit and morphological specificity of synaptic change in the aged hippocampal formation. Neurobiol. Aging 20, 357-358.

Solomon, P. R., and Moore, J. W. (1975). Latent inhibition and stimulus generalization of classically-conditioned nictitating-membrane response in rabbits (oryctolagus-cuniculus) following dorsal hippocampal ablation. J Comp. Physiol. Psychol. 89, 1192-1203.

Solomon, P. R., Pomerleau, D., Bennett, L., James, J., and Morse, D. L. (1989). Acquisition of the classically-conditioned eyeblink response in humans over the life-span. Psychol. Aging 4, 34-41.

Solomon, P. R., Solomon, S. D., Vanderschaaf, E., and Perry, H. E. (1983). Altered activity in the hippocampus is more detrimental to classical conditioning than removing the structure. Science 220, 329-331.

Somayajulu-Nitu, M., Sandhu, J. K., Cohen, J., Sikorska, M., Sridhar, T. S. Matei, A., Borowy-Borowski, H., and Pandey, S. (2009). Paraquat induces oxidative stress, neuronal loss in substantia nigra region and Parkinsonism in adult rats: neuroprotection and amelioration of symptoms by watersoluble formulation of coenzyme $\mathrm{Q}_{10}$. BMC Neurosci. 10, 88-99. doi 10.1186/1471-2202-10-88

Sternberg, E. M., Glowa, J. R., Smith, M. A., Calogero, A. E., Listwak, S. J., Aksentijevich, S., Chrousos, G. P., Wilder, R. L., and Gold, P. W. (1992). Corticotropin releasing hormone related behavioral and neuroendocrine responses to stress in Lewis and Fischer rats. Brain Res. 570, 54-60.

Stoehr, J. D., and Wenk, G. L. (1995). Effects of age and lesions of the nucleus basalis on contextual fear conditioning. Psychobiology 23, 173-177.

Sumien, N., Sims, M. N., Taylor, H. J., and Forster, M. J. (2006). Profiling psychomotor and cognitive aging in four-way cross mice. Age 28, 265-282.
Sutherland, R. J., and Rudy, J. W. (1989). Configural association theory: the role of the hippocampal formation in learning, memory and amnesia. Psychobiology 17, 129-144.

Thompson, L. T., Moyer, J. R., and Disterhoft, J. F. (1996). Trace eyeblink conditioning in rabbits demonstrates heterogeneity of learning ability both between and within age groups. Neurobiol. Aging 17, 619-629.

Thompson, R. F. (1986). The neurobiology of learning and memory. Science 233, 941-947.

Thompson, R. F., Berger, T. W., and Madden, J. (1983). Cellular processes of learning and memory in the mammalian CNS. Annu. Rev. Neurosci. 6 , $447-491$.

Thouvarecq, R., Protais, P., Jouen, F., and Caston, J. (2001). Influence of cholinergic system on motor learning during aging in mice. Behav. Brain Res. 118, 209-218.

Tseng, W., Guan, R., Disterhoft, J. F., and Weiss, C. (2004). Trace eyeblink conditioning is hippocampally dependent in mice. Hippocampus 14, 58-65.

van Praag, H., Qu, P. M., Elliott, R. C., Wu, H., Dreyfus, C. F., and Black, I. B. (1998). Unilateral hippocampal lesions in newborn and adult rats: effects on spatial memory and BDNF gene expression. Behav. Brain Res. 92 21-30.

van Praag, H., Shubert, T., Zhao, C. M., and Gage, F. H. (2005). Exercise enhances learning and hippocampal neurogenesis in aged mice. J. Neurosci. 25, 8680-8685.

Villarreal, J. S., Dykes, J. R., and BareaRodriguez, E. J. (2004). Fischer 344 rats display age-related memory deficits in trace fear conditioning. Behav. Neurosci. 118, 1166-1175.

Vogel, R. W., Ewers, M., Ross, C., Gould, T. J., and Woodruff-Pak, D. S. (2002). Age-related impairment in the 250-millisecond delay eyeblink classical conditioning procedure in C57BL/6 mice. Learn. Mem. 9, 321-336.

Voikar, V., Koks, S., Vasar, E., and Rauvala, H. (2001). Strain and gender differences in the behavior of mouse lines commonly used in transgenic studies. Physiol. Behav. 72, 271-281.

Weible, A. P., McEchron, M. D., and Disterhoft, J. F. (2000). Cortical involvement in acquisition and extinction of trace eyeblink conditioning. Behav. Neurosci. 114, 1058-1067.

Weible, A. P., Oh, M. M., Lee, G., and Disterhoft, J. F. (2004). Galantamine facilitates acquisition of hippocampus-dependent trace eyeblink conditioning in aged rabbits. Learn. Mem. $11,108-115$. 
Weiss, C., Bouwmeester, H., Power, J. M., and Disterhoft, J. F. (1999). Hippocampal lesions prevent trace eyeblink conditioning in the freely moving rat. Behav. Brain Res. 99, 123-132.

Weiss, C., and Thompson, R. F. (1992). Delayed acquisition of eyeblink conditioning in aged F1-hybrid (Fischer $344 \mathrm{x}$ Brown Norway) rats. Neurobiol. Aging 13, 319-323.

West,M.J.(1993). Regionally specificloss of neurons in the aging human hippocampus. Neurobiol. Aging 14, 287-293.

West, M. J., Coleman, P. D., Flood, D. G., and Troncoso, J. C. (1994). Differences in the pattern of hippocampal neuronal loss in normal aging and Alzheimer's disease. Lancet 344, 769-772.

Whishaw, I. Q. (1995). A comparison of rats and mice in a swimming pool place task and matching to place task: some surprising differences. Physiol. Behav. 58, 687-693.

Whishaw, I. Q., and Tomie, J. A. (1996). Of mice and mazes: similarities between mice and rats on dry land but not water mazes. Physiol. Behav. 60, 1191-1197.

Wiltgen, B. J., Sanders, M. J., Behne, N. S., and Fanselow, M. S. (2001). Sex differences, context preexposure, and the immediate shock deficit in Pavlovian context conditioning with mice. Behav. Neurosci. 115, 26-32.

Wong, A. A., and Brown, R. E. (2007). Age-related changes in visual acuity, learning and memory in C57BL/6J and DBA/2J mice. Neurobiol. Aging 28, 1577-1593.

Woodruff-Pak, D. S. (1988). Aging and classical conditioning: parallel studies in rabbits and humans. Neurobiol. Aging 9, 511-522.

Woodruff-Pak, D. S. (1990). "Mammalian models of learning, memory, and aging," in Handbook of the Psychology of Aging, 3rd Edn., eds J. E. Birren and K. W. Schaie (New York: Academic Press), 235-257.

Woodruff-Pak, D. S. (2006). Stereological estimation of Purkinje neuron number in C57BL/6 mice and its relation to associative learning. Neuroscience 141, 233-243.

Woodruff-Pak, D. S., Cronholm, J. F., and Sheffield, J. B. (1990). Purkinje cell number related to rate of classical conditioning. Neuroreport 1, 165-168.

Woodruff-Pak, D. S., and Disterhoft, J. F. (2008). Where is the trace in trace conditioning? Trends Neurosci. 31, 105-112.

Woodruff-Pak, D. S., Ewers, M., Shiotani, T., Watabe, S., Tanaka, M., and Wenk, G. L. (2004). Nefiracetam and physostigmine: separate and combined effects on learning in older rabbits. Neurobiol. Aging 25, 807-816.

Woodruff-Pak, D. S., and Finkbiner, R. G. (1995). Larger nondeclarative than declarative deficits in learning and memory in human aging. Psychol. Aging. 10, 416-426.

Woodruff-Pak, D. S., Foy, M. R., Akopian, G. G., Lee, K. H., Zach, J., Nguyen, K. P. T., Comalli, D. M., Kennard, J. A., Agelan, A., and Thompson, R. F. (2010). Differential effects and rates of normal aging in cerebellum and hippocampus. Proc. Natl. Acad. Sci. U.S.A. 107, 1624-1629.

Woodruff-Pak, D. S., Foy, M. R., and Thompson, R.F. (2009)."Contribution of a mouse model system to neuroscientific theories of learning, memory, and aging," in Handbook of Theories of Aging, 2nd Edn., eds V. L. Bengston, D. Gans, N. M. Pulney, and M. Silverstein (New York: Springer Publishing Co.), 193-213.

Woodruff-Pak, D. S., Green, J. T., Levin, S. I., and Meisler, M. H. (2006).
Inactivation of sodium channel $\mathrm{Scn} 8 \mathrm{~A}(\mathrm{Na}(\mathrm{v}) 1.6)$ in Purkinje neurons impairs learning in Morris water maze and delay but not trace eyeblink classical conditioning. Behav. Neurosci. 120, 229-240.

Woodruff-Pak, D. S., and Jaeger, M. E. (1998). Predictors of eyeblink classical conditioning over the adult age span. Psychol. Aging 13, 193-205.

Woodruff-Pak, D. S., Lavond, D. G., and Thompson, R. F. (1985). Trace conditioning: abolished by cerebellar nuclear lesions but not lateral cerebellar cortex aspriations. Brain Res. 348, 249-260.

Woodruff-Pak, D. S., Lavond, D. G. Logan, C., and Thompson, R. F. (1987). Classical conditioning in 3-, 30-, and 45-month old rabbits: behavioral learning and hippocampal unit activity. Neurobiol. Aging 8, 101-108.

Woodruff-Pak, D. S., and Li, Y. (1994). Nefiracetam (DM-9384): effect on eyeblink classical conditioning in older rabbits. Psychopharmacology 114, 200-208.

Woodruff-Pak, D. S., Seta, S. E., Roker, L. A., and Lehr, M. A. (2007a). Effects of paradigm and inter-stimulus interval on age differences in eyeblink classical conditioning in rabbits. Learn. Mem. 14, 287-294.

Woodruff-Pak, D. S., Tobia, M. J., Jiao, X., Beck, K. D., and Servatius, R. J. (2007b). Preclinical investigation of the functional effects of memantine and memantine combined with galantamine or donepezil. Neuropsychopharmacology 32 , 1284-1294.

Woodruff-Pak, D. S., and Steinmetz, J. E. (Eds.). (2000a). Eyeblink Classical Conditioning: Applications in Humans, Vol. 1. Boston: Kluwer Academic Publishers.
Woodruff-Pak, D. S., and Steinmetz, J. E. (Eds.). (2000b). Eyeblink Classical Conditioning: Animal Models, Vol. 2. Boston: Kluwer Academic Publishers.

Woodruff-Pak, D. S., and Thompson, R. F. (1988). Classical conditioning of the eyeblink response in the delay paradigm in adults aged $18-83$ years. Psychol. Aging 3, 219-229.

Woodruff-Pak, D. S., Vogel, R. W., and Wenk, G. L. (2001). Galantamine: effect on nicotinic receptor binding, acetylcholinesterase inhibition, and learning. Proc. Natl. Acad. Sci. U.S.A. 98, 2089-2094.

Yamazaki, M., Matsuoka, N., Maeda N., Kuratani, K., Ohkubo, Y., and Yamaguchi, I. (1995). FR121196, a potential antidementia drug, ameliorates the impaired memory of rat in the Morris water maze. J. Pharmacol. Exp. Ther. 272, 256-263.

Conflict of Interest Statement: The authors declare that the research was conducted in the absence of any commercial or financial relationships that could be construed as a potential conflict of interest.

Received: 29 March 2011; paper pending published: 24 April 2011; accepted: 13 May 2011; published online: 25 May 2011.

Citation: Kennard JA and Woodruff-Pak DS (2011) Age sensitivity of behavioral tests and brain substrates of normal aging in mice. Front. Ag. Neurosci. 3:9. doi: 10.3389/ fnagi.2011.00009

Copyright $\odot 2011$ Kennard and WoodruffPak. This is an open-access article subject to a non-exclusive license between the authors and Frontiers Media SA, which permits use, distribution and reproduction in other forums, provided the original authors and source are credited and other Frontiers conditions are complied with. 